\title{
AUTHORS' AND PERFORMERS' RIGHTS
}

\author{
Herbert T. Silverberg*
}

I

INTRODUCTION

In future days, some historian may refer to the present decade as the age of television. Certainly, the importance of television is a phenomenon not to be discounted. It has been estimated that as of the first half of 1957 , there were over 44 million television sets in use in this country, as compared to less than $I 7$ million in 1952. Television advertising revenue for 1957 has been estimated at 1.3 billion dollars; it is expected to reach 2 billions per annum within the coming five years. Already the advertising revenue for television exceeds the total receipts of all motion picture theaters in the United States. ${ }^{2}$

A justification for the willingness of advertisers to pour these huge sums into television is the estimate that, in 1957 , more people spent more hours watching television programs (including motion pictures on television) than on any other form of cultural preoccupation, such as attending cinemas, listening to the radio, or reading books, newspapers, and magazines. ${ }^{3}$ The growth of the television audience naturally has enhanced the importance of the rights and privileges of creators, producers, and performers of television shows. For example, the importance of the endorsement of a product by a star is much more valuable when that endorsement will be seen over If million American television sets. ${ }^{4}$ The sacrifice of anonymity and privacy on the part of the star is worth much more when that sacrifice is made before the eyes of a tremendous television audience, instead of a comparatively limited motion picture or theatrical audience.

Furthermore, television has proved a voracious consumer of talent. Consequently, ample payment for performance rights is vital to the performer because of the danger of saturating the television market with his personality and the consequent loss of his ability to attract demand for his services. The recent eclipse of such luminaries

* LL.B. 1927, LL.M. I929, St. Lawrence University. Member of the California and New York bars. Grateful acknowledgment is made to Professor Robinson O. Everett, of the Duke Law School, for his invaluable revision and editing of this article; without him, there would have been no article.

${ }^{1}$ r957-58 Telecasting YeARBook-MarketbooK 429; Broadcasting-Telecasting, March 10, 1952, p. 66, col. 4 .

Eric Johnston, speech to T.O.A. Convention, as reported in Broadcasting, Nov, 25, I957.

${ }^{3}$ Survey by Sindlinger and Company, as reported in How People Spend Their Time, Broadcasting, Dec. 2, 1957, p. 44. Indeed, more time is spent on watching television than on any other activity except sleeping: 2.6 billion person-hours every week on television versus 1.9 billion on all economic pursuits. See i958 International Tezevision Almanac i6A.

'See Wyatt Earp Enterprises, Inc. v. Sackman, Inc., I57 F. Supp. 621, 624-25 (S.D.N.Y. 1958). 
as Milton Berle and Jackie Gleason has highlighted the transitory nature of high Trendex ratings.

Associated, perhaps, with the development in recent years of cinema and now television has been the ever-increasing preoccupation of the American people with stars and personalities. Stemming, in turn, from this preoccupation has been an increased development of techniques for cashing in on popularity. Perhaps the ingenuity displayed in realizing revenues from a star's popularity is related to the circumstance just noted that in television, glory fades swiftly, and that, therefore, hay must be made while the sun is still shining. In any event, one has only to note the numerous articles of merchandise sold with the indorsement of some star or personality in the motion picture or television field to realize the significance of efforts to trade popularity for cash through merchandising articles which are sometimes not even remotely connected with the personality of the star.

In light of such changes in the economics of entertainment-changes which have been accentuated by television-it is not surprising to note concomitant legal developments. To some extent, these developments have taken place via the case law. Judges have become more prone to protect a person who contributes either ideas or services to television as those judges gained new awareness of the value of the television product..$^{5}$ Many things which at one time might have been shrugged off by a judge with the comment de minimis non curat lex are now viewed differently because of the daily proof of their economic importance. Perhaps, too, the courts have become more desirous of avoiding unjust enrichment of a businessman through misappropriation of artistic ideas or services. Indeed, this desire may lie at the basis of the tendency of some courts-a tendency decried by Mr. Olsson in his article in this symposium-to protect judicially the progenitor of even the crudest idea that turns out to yield a profit.

Not only court decisions, but also statutes and treaties, both in the United States and abroad, have been a vehicle for the recognition and protection of expanding property interests in the motion picture, broadcasting, and telecasting field. More important as a practical matter-at least in the United States-has been the protection afforded both author and performer by means of collective bargaining and by creation of strong guilds to represent them. Some aspects of this collective bargaining have been treated elsewhere in this symposium by Messrs. Gilbert and Tower, but they also will "be noted here where relevant. Still another method for extension of the author's or performer's rights has been the development of new talent contract

${ }^{5}$ See, e.g., Chandler v. Roach, ${ }_{5} 6$ Cal.App.2d 507, 116 U.S.P.Q. 263 (1957), petition for hearing denied, California Supreme Court, Feb. 26, 1958, where a California appellate tribunal held that even an idea without novelty would be protected under an express or implied-in-fact contract; the case involved use of an idea for a television series based on the activities of the public defender's office. See also Desny v. Wilder, 46 Cal.2d 715, 299 P.2d 257 (1956), concerning the idea for a theatrical motion picture based on the Floyd Collins incident. This decision is discussed extensively, elsewhere in this symposium, from the network and producer's standpoint by Mr. Olsson of NBC. But see Heckenkamp v. Ziv Television Programs, Inc., 157 Cal.App.2d 31 I (1958). 
provisions which reflect the diversified demands for protection of the persons who write for or act in the movies and television.

In the following portions of this article, an attempt will be made to examine some of the more significant legal developments which pertain to recognition of new property interests in the entertainment industry -and particularly in radio and television-and also to some of the economic methods for protecting those interests. The discussion will center on authors and performers, although many of the observations here will also pertain to directors, producers, and other persons who are connected with radio and television.

II

\section{Protection of Authors}

\section{A. The Copyright Act}

Basic to a television show is its script. Filmed shows inevitably require script, as do most live dramatic programs. Indeed, it has been rumored that even "spontaneous" quiz shows occasionally utilize scripts for their entertainment portion. Both live television and filmed shows frequently draw their plot from a copyrighted previous literary work, such as a novel or a short story. For these reasons, copyright laws are extremely important in determining what can go over the airwaves and who will receive money therefor.

In some European countries, as will be hereafter discussed, a copyright in a composite work, such as a film or a television show, may be split up among the several contributors, and the various rights inherent in a copyright may be sold separately to different owners. This multiple concept is particularly apparent in the French law. In the United States, the concept of copyright is a unitary one, in the sense that the rights cannot be split up by partial assignment-either as to time, place, or as to particular rights or privileges. ${ }^{6}$ Utilization of the copyright by one other than the original holder must be through an assignment of the whole copyright or through an exclusive or nonexclusive license. Thus, if an author "sells" motion picture rights, he merely licenses the producer to make a film or telecast from his work, and if thereafter some third person infringes the original work, for instance, by making another film from it, the licensee cannot in his own name sue the infringer; but instead he may join the copyright proprietor as plaintiff or defendant in the infringement suit. This, however, does not necessarily apply to situations outside the copyright field.

The tax treatment of the payments received by a copyright owner for use of that copyright has been considered by the courts several times. In one case, the court of claims-in light of economic realities and the statutory provisions for independent, although derivative, copyright of a motion picture-concluded that an exclusive grant

\footnotetext{
${ }^{\circ}$ For the French law, see, e.g., Henri Desbois, Le Droir D' Auteur (1950). Cf. M. Witmark \& Sons v. Pastime Amusement Co., 298 Fed. 470 (E.D.S.C. 1924), aff'd, 2 F.2d 1020 (4th Cir. 1924). See 2 Harry P. Warner, Radio and Television Rights $\$$ I53 (1953).
} 
of motion picture rights to a novel constituted a "sale," despite the circumstances that all rights other than movie rights had been retained by the author and that, for copyright purposes, only a "license" was involved." The Treasury Department has now officially adopted the rule of this decision. ${ }^{8}$ Yet, questions remain. Would a grant of radio or television rights receive the same treatment tax-wise? ${ }^{0}$ What residual rights could be retained by the original author without a change in result? And does it make any difference whether compensation to the copyright holder involves a percentage of ultimate profits from use of the copyright?

Outside the tax field ${ }^{10}$ the distinction between an assignment of a copyright or a mere license to use it is significant as to procedural problems, ${ }^{11}$ renewal copyrights, ${ }^{12}$ and the implied negative covenant of a grantor not to use ungranted portions of his copyright to the detriment of his licensee. ${ }^{13}$

In the United States, when a writer is an employee for hire, he falls within the express provision of the Copyright Act that-by a sort of legal fiction-his employer shall be considered the "author" of any such "work made for hire."14 This unique legal provision, together with the realities of the master-servant relationship, lends plausibility to the theory that the employee has no rights in either the substance of the material or the copyright therein. An employee's registration of a claim to copyright of a work made while he was employed for hire will not protect him if it is clear that the work was created within the scope of his employment. ${ }^{15}$ Thus, a map-

\footnotetext{
${ }^{7}$ Herwig v. United States, I05 F. Supp. 384, 388-89 (Ct. Cl. 1952); see also Gershwin v. United States, 153 F. Supp. 477 (Ct. Cl. 1957). But cf. Cory v. Commissioner, 230 F.2d 941 (2d Cir. 1956), cert. denied, 352 U.S. 828 (1957), wherein the court of appeals mentioned but did not rule on this point. But see I.R.C. $\$ 636$.

${ }^{8} 8$ Rev. Rul. 54-409, I954-2 Cum. BuLz. 174.

${ }^{9}$ In appraising the soundness of the reasoning of the court of claims in Herwig v. United States, ro5 F. Supp. $3^{84}$ (Ct. Cl. 1952 ) and in dealing with related problems, it should be noted that it is possible for independent derivative copyrights to exist in both a motion picture and television film based upon a copyrighted literary property. Thus, a copyright owner who grants movie rights is better cnabled to say that he has "sold" one thing and that the television rights he retains are something entirely distinct. And vice versa when the television rights are granted.

${ }^{10}$ For additional problems in the tax field, see Fields v. Commissioner, I89 F.2d 950 (2d Cir. 1952); Commissioner v. Reese, 233 F.2d 30 (xst Cir. t956); and Pilpel, Tax Laws Affecting Copyrights, 19541956, 35 TAXES 76 (1957). Historical data are presented in WARNER, op. cit. supra note 6, 855 ; Greenbaum, The Professional Writer, 15 NYU Institute of Feneral Taxation 269 (1957).

${ }^{11}$ FED. R. Crv. P. I9(a); Field v. True Comics, 89 F. Supp. 6ri (S.D.N.Y. I950); Widenski v. Shapiro, Bernstein \& Co., $x_{47}$ F.2d 909 (rst Cir. 1945); Goldwyn Pictures v. Howell Sales Co., 282 Fed. 9 (2d Cir. 1922). As to the rights of joint authors, see Anderson v. Educational Publishers, 133 F. Supp. 82 (D. Minn. r950); Stowe v. Gray, 284 App. Div. 302, I30 N.Y.S.2d 848 (rst Dep't 1954).

${ }^{12}$ Ricordi v. Paramount Pictures, Inc., 98 F. Supp. 537 (S.D.N.Y. 1950), modified, r89 F.2d 469 (2d Cir.), cert. denied, 342 U.S. 849 (I95I).

${ }^{13}$ Manners v. Morosco, 252 U.S. 317 (I920). If an author has granted an interest in motion picture rights to a theatrical producer who presents the work on the stage, the theatrical producer is cntitled not only to a share of the movie license fees, but also to a share of any recovery in a suit for copyright infringement of the movie. MeClintic v. Sheldon, 269 App. Div. 356, 55 N.Y.S.2d 879 (Ist Dep't 1945).

14 6r STAT. 652 (1947), I7 U.S.C. $\$ 26$ (I952).

${ }_{15}$ Yardley v. Houghton-Miffin Co., 25 F. Supp. $36 \mathrm{I}$ (S.D.N.Y. 1938), afjd, ro8 F.2d 28 (2d Cir. 1939), cert. denied, 309 U.S. 686 (1940); Brown v. Molle, 20 F. Supp. 135 (S.D.N.Y. 1937); Philips v. WGN, 307 Ill. App. I, 29 N.E.2d 849 (1940).
} 
maker employed by the government was said to hold in trust for his employer a copyright obtained on the maps he produced. ${ }^{16}$

Authors use two escapes from this employee-for-hire dilemma: (I) entry into contracts for the purchase of his product rather than into contracts for his employment; or (2) in any contracts of employment, inclusion of specific reservations of the copyright or of the ungranted right. And so a bill of sale designating as the "sole owner and author" a writer receiving a weekly salary was held to constitute evidence of a sales contract rather than an employment contract. ${ }^{17}$ Tending in the opposite direction is the doctrine of cases where the courts have said in effect that, unless otherwise provided for by contract, a writer transferred all his rights in a story or article to the publisher. ${ }^{18}$

In dealing with the television producer, the Writers' Guild has strenuously tried to overcome the practice, traditional in the motion picture industry, of giving the producer a complete assignment of all rights. Where it can, the Guild now insists on a separation of rights-not only for the independent contractor, but also for the employed author-so that the author may use his television material for transformation into a book, play, or motion picture for his own benefit, although subject to certain equitable limitations for the benefit of the producer. The concern of the author is not necessarily so much in obtaining for himself the copyright of the television play, but in being assured that the producer will obtain the necessary copyright protection so that the writer will later have an opportunity to exploit the property in other media. ${ }^{19}$

In the same context, it should be noted that an author is not necessarily precluded from copyrighting a work produced under an employment contract. Instead, the intent of the parties-as reflected by the contract-concerning which of them shall have the copyright is decisive. When the employment contract is silent, the presumption is usually in favor of the employer, ${ }^{20}$ but this presumption may be contradicted by other circumstances of the case. ${ }^{21}$

The fine points which may determine ownership of literary material as between

${ }^{10}$ Sawyer v. Crowell Pub. Co., 46 F. Supp. 497 (S.D.N..Y. I942), affd, I42 F.2d 497 (2d Cir. I943), cert. denied, 323 U.S. 735 (1944); Bleistein v. Donaldson Lithograph Co., x 88 U.S. 239 (1903); Brown v. Molle, supra note 15. Cf. United States v. First Trust Co., Ir6 U.S.P.Q. 172, 173 (8th Cir. 1958). As to employees' rights in inventions, see Bishop, Employers, Employees, and Inventions, 3 I So. CaLIF. L. REv. $3^{8}$ (1957).

${ }^{17}$ Shapiro, Bernstein \& Co. v. Jerry Vogel Music Co., 67 U.S.P.Q. I2 (S.D.N.Y. 1945), reversed on other points and remanded, 158 F.2d 757 (2d Cir.), $16 \mathrm{r}$ F.2d 406 (2d Cir. 1946 ), on remand, $73 \mathrm{~F}$. Supp. 165 (S.D.N.Y. I947). But see Otten v. Curtis Pub. Co., 91 U.S.P.Q. 222 (N.Y. Sup. Ct. I95I).

${ }^{18}$ Mifflin v. White, $x 12$ Fed. 1004 (Ist Cir. I902), aff'd, x90 U.S. 260 (Ig03); Simonton v. Gordon, I2 F.2d II6 (S.D.N.Y. I925); Dam v. Kirk La Shelle Co., I75 Fed. 902 (2d Cir. 1910); White-Smith Music Co. v. Apollo, I39 Fed. 427 (S.D.N.Y. I905), affd, x47 Fed. 226 (2d Cir. I907), aff'd, 209 U.S. I (1908); Otten v. Curtis Pub. Co., supra note I7.

${ }_{10}$ Variety, Oct. 17, I956, reported that the Writers' Guild of America will propose a change in the copyright law to the effect that unpublished stories would be separately copyrighted and could be licensed to the producer in any manner that suits the authors.

${ }^{20}$ Anderson v. Baldwin Law. Pub. Co., 27 F.2d 82 (6th Cir. 1928). See also Storer Broadcast Co. v. Jack the Bellboy, I07 F. Supp. 988 (E.D. Mich. I952).

${ }^{31}$ See Otten v. Curtis Pub. Co., 91 U.S.P.Q. 222 (N.Y. Sup. Ct. 1951). 
employer and employee in the broadcasting context are illustrated by $U$ proar Co. $u$. $N B C .^{22}$ There, the federal circuit court held that scripts prepared by comedian Ed Wynn as an employee of the Texas Company were, nonetheless, his property rather than that of his employer. Although Wynn received separate and additional compensation for preparing the script, the court found that he was employed primarily as a performer rather than as a writer. Since the contract of employment was silent as to ownership of the scripts and the employer had regarded them as having small intrinsic value, the court held that there was no implied term of assignment of literary material. In ruling against the employer, the court did, however, recognize its right to be protected against a detrimental use of the material under the principle laid down by the United States Supreme Court in Manners $v$. Morosco. ${ }^{23}$

At the time of the original contract, the end of the 28 -year period of the original copyright seems a long time off. But a television film telecast this week or a motion picture released yesterday may contain music or be derived from a published work on which the original period of the copyright has expired. Not only must the producer of the film determine the person or persons to whom royalties are due under any renewal copyright, but he must confront the more immediate and disturbing problem as to whether he obtained in the first instance an assignment or license which will allow broadcast or exhibition during the period of a renewal copyright. The penalty for oversight may be a suit for infringement.

In Ricordi v. Paramount Pictures, Inc., ${ }^{24}$ a federal court held that the owner of the renewal copyright in the original work may require a new license for the further transformation of any matter taken from the original. Though it was indicated that the assignee or licensee had rights which arose from the new matter on which was based its derivative but independent copyright, the court did not reveal how these rights could be exercised without using again and thereby infringing the renewal copyright in the material on which it was originally based. Clearly, careful practice requires that a license extending through the copyright renewal period be obtained even when the producer considers that the amount of the material to be used from the original work may seem too small to warrant such precaution.

Even the most cautious film or television producer is also faced with the

22 8 F. Supp. 358 (D. Mass. I934), modified, 81 F.2d 373 (Ist Cir.), cert. denied, 298 U.S. 670 (1936).

252 U.S. 317 (1920).

2492 F. Supp. 537 (S.D.N.Y. I950), modified, $\times 89$ F.2d 469 (2d Cir.), cert. denied, 342 U.S. B4I (195r).

There is some room for a different interpretation of the full import of this case. Ricordi originally brought a suit in the district court to secure a declaratory judgment that he was the sole and cxclusive owner of movie rights in the opera Madame Butterfly and asked that Paramount be enjoined from claiming any adverse ownership of those rights. The district court granted a summary judgment for Ricordi with an injunction against Paramount. The decree of the district court was modified in some respects by the court of appeals. It is interesting, however, that the district court, which had relied heavily on Edmonds v. Stern, 248 F.897 (2d Cir. 1918), was not specifically contradicted by the appellate court in its view that when the opera Madame Butterfly was finally created, it was the subject of copyright and could be duly copyrighted; that it was a substantially new and distinct composition; and that it was a piece of property wholly separate and independent from the novel and the drama. 
difficulty created by the legal rule that an author's heirs or successors are not bound by any assignment or licensing agreement on his part purporting to extend through the period of the renewal copyright unless (a) the author is alive at the time of renewal and can, therefore, be held to his contract, or (b) the heirs or successors were themselves parties to the original assignment or license agreement. ${ }^{25}$ Consequently, it is now customary to try to obtain the signatures of prospective heirs on any agreement involving an assignment or license which it is desired to extend into the period of a renewal copyright.

The creator of a script may have an interest not only in the plot and the dialogue, but also in the characters created. Even in motion pictures, it was not unusual for several films to revolve around the same characters-witness the Tarzan or Andy Hardy series. In television programming, the serial or sequel story with a continued cast of more or less permanent characters is a staple. The advertiser seems happiest with a popular fictional character with enduring life, just like some of the venerable but ever-young comic-strip characters. In Warner Bros. Pictures, Inc. v. CBS, ${ }^{26}$ the Federal Court of Appeals for the Ninth Circuit has recently considered the extent to which a writer's interest in the characters he creates may be protected. There it was held that the author of the detective story, The Maltese Falcon, was free to use for radio the characters in that story, which the defendant had originally purchased from him for motion picture use, since the specific enumeration of items in the agreement of purchase did not include the characters or character names. The court recognized that "historically and presently detective fiction writers have and do carry the leading character with their name and individualisms from one story into succeeding stories." However, the court was of the opinion that in as much as copyright law did not cover and, therefore, did not protect characters and their names, an assignment of copyright in a story did not transfer the rights in the characters or prevent the author from using them, unless he was specifically restrained by contract. (Of course, the lesson of this case has been heeded by the draftsmen of contracts for the purchase of motion picture and television rights.)

\section{B. Authors' Guilds}

The work of professional writers employed by motion picture producers has been by far the largest source of motion picture stories. In the two decades ending in 1955, they furnished 63.3 per cent of all story material for motion pictures. ${ }^{27}$ In television, undoubtedly, the importance of the professional writer has been equally great, if not greater.

Writers for theatrical or television films are usually hired either on a "term

${ }^{20}$ See Fisher Music Co. v. Witmark, 38 F. Supp. 72 (S.D.N.Y. 194r), afjd, r25 F.2d (2d Cir. 1942), 318 U.S. 643 (1943); Miller Music Corp. v. Charles N. Daniels, Inc., I58 F. Supp. 188 (S.D.N.Y. I957).

${ }_{36} 216$ F.2d 945, 949 (9th Cir. 1954), cert. denied, 348 U.S. 97 I (1955).

${ }^{27}$ Motion Picture Ass'N of Ameruch, Inc., 1955 Anv. Rep. 19 (r956). Free-lance writers contributed nearly one-fourth of the stories for feature length pictures; about $6.2 \%$ came from stage plays. An interesting chart on source material in terms of original screen stories, stage plays, and novels is contained in the weekly, Variety, Feb. 26, 1958, p. 4. 
basis"-i.e., for a number of works-or a "deal basis"-i.e., for work on an individual picture or series of pictures. It seems that "term employment" in theatrical picture production is rapidly decreasing, while in the production of television pictures, it has been increasing. ${ }^{28}$

On whatever basis employed, the writers of material for movies and for television are represented by guilds. The Authors' League of America consisted at first primarily of novelists, short-story writers, and some playwrights. By 1920, however, the screen writers, feeling it desirable to deal with their own problems on a separate basis, though within the framework of the Authors' League, organized the Screen Writers' Guild. In I937, the Radio Writers' Guild, and in 1949, the Television Writers' Guild, came into existence, both also within the framework of the Authors' League.

In 1954, an amalgamation took place which resulted in the Writers' Guild of America, that now represents screen, television, and radio writers in WGA East and WGA West. The western branch has about 1500 members, of whom 700 are screen writers, 200 double as TV writers, 300 write for TV only, and the remainder write for TV and radio or combine all three functions. The eastern branch has about 600 members, of whom around 400 are exclusively employed in television. Incidentally, there is currently some pressure for further amalgamation, it having been proposed that WGA should combine under "one big umbrella" with the Dramatists' Guild (legitimate playwrights) and with the Authors' League. ${ }^{29}$

The strength of the various guilds that have represented the writer may, to a great extent, account for his economic gains. In fact, by reason of guild activity, American writers have attained an economic position apparently far superior to that of their European colleagues who, in a number of countries, are given superior protection as far as legal theory is concerned. A primary concern of the guilds in the United States has been to assure the preparation of basic standard contracts which fully protect all interests of the writer, however remote. Thus, as previously noted, the Writers' Guild and others have attempted to reserve for their members rights of exploitation in media other than the one in which the material is originally being used. Of course, sometimes the Guild will recognize the right of the producer to participate in the exploitation of the story in other media.

Among the -most important functions of the Writers' Guild are those in connection with credits for authorship. As is becoming increasingly apparent, a credit line in a movie or television production may mean not only increased prestige, but also money in the bank for the beneficiary thereof. ${ }^{30}$ This is particularly so as to

\footnotetext{
${ }^{28}$ As of Dec. 4, x956, Variety (Dec. 5, 1956), reported "Only 24 Writers now 'Employees' of Big Studios"; Irg were on a "deal" basis. On the other hand, Variety (May 16 , 1956), reported that a single television film producer (Screen Gems, a subsidiary of Columbia Pictures) had 60 writers on the payroll working on scripts for xo telefilm series; it is assumed that the phrase "on the payroll" indicatcs term employment.

${ }^{20}$ See Variety, Dec. 7, 1955.

${ }^{30}$ However, in the recent case of Zorich v. Petroff, I52 Cal. App. 2d 806, 8xx, 313 P.2d 118 (1957), the appellate court affirmed the trial court's determination that plaintiff had suffered no damage from
} 
"residual rights," which by contractual agreement are predicated on credit lines and. only exist in favor of one who receives a "credit." These economic realities have led. to judicial recognition of this importance of credits, as in the recent case of Poe v. Michael Todd Co., where Federal Judge Weinfeld commented, “A writer's reputation, which would be greatly enhanced by public credit for authorship of an outstanding picture, is his stock in trade; it is clear that irreparable injury would follow the failure to give him screen credit if in fact he is entitled to it." ${ }^{\text {"11 }}$

To secure the economic and honorific benefit of screen and television credits for writers, WGA has undertaken to administer claims for credit and has thereby relieved producers from the thankless task of arbitrating between rival authors. It has been estimated that there are 150 cases annually on motion picture credits. In I955, there were some 1250 tentative notices of credit filed with the Guild for film television credits. $^{32}$

Neither the copyright law nor any other applicable statute specifically deals with screen credits, and, thus, the WGA, in this field, operates almost autonomously. To preclude the necessity of judicial intervention, the Guild, in its Minimum Basic Agreement, requires producers to agree in Schedule $A$ that:

The decision of the Guild ... with respect to writing credits, in so far as it is rendered. within limitations of this Schedule A, shall be final. ...

No writer or Producer shall be entitled to collect damages or shall be entitled to injunctive relief as a result of any decision of the Committee with regard to credits . . . ; any writer or Producer specifically waives all rights of claims against the Guild ... under the laws of libel or slander or otherwise. ...

\section{The "Moral Right" and Fair Use}

To secure merely an assignment of motion picture or television rights from an author frequently falls short of giving the producer sufficient freedom of action in adapting the purchased work for his purposes. The producer usually wishes to have an unrestricted right to use the material in any fashion he deems bestparticularly, "to freely adapt, change, transpose, revise, rearrange, add to and subtract ... to make interpolations in and substitutions for any part or parts ... to use any part of the work or of the theme ... or any incidents, characters, scenes, sequences or characterizations ... in conjunction with any other work or works, ${ }^{, 33}$ as the pro. ducer in his sole discretion may find expedient. Sometimes, the producer finds that the "moral right" of the author is in conflict with this desire for unlimited discretion. This phrase "moral right" is generally understood to mean the author's

the failure to give him screen credit as associate producer of a motion picture which had turned out to bea financial failure.

${ }^{31}$ I5I F. Supp. 801, 803 (S.D.N.Y. I957). The Writers' Guild agrees and notes in its Credits Manual: "A writer's position in the motion picture or television industry is determined largely by his credits. His salary status depends on the quality and number of screenplays, teleplays, or stories which bear his. name."

${ }^{32}$ Information supplied by Writers' Guild.

${ }^{83}$ Such provisions appear in many producer-writer contracts. 
right to claim authorship and to defend the integrity of his work. Occasionally, the rights to create a work, to publish it, or withdraw it from circulation, or to prevent any violation of the author's professional personality, have also been included in the moral right doctrine. ${ }^{34}$

The "moral right," as such, has never received in American jurisprudence the express recognition that it has attained from continental jurists. The late Judge Jerome N. Frank noted, "The phrase 'moral right' seems to have frightened some of those courts in some American jurisdictions to such an extent that they have unduly narrowed artists' rights."35 Yet, as Judge Frank also observed, the same courts have at the same time recognized a considerable number of the rights in this particular bundle under other names such as defamation, unfair competition, and right of privacy. ${ }^{36}$

In a recent article discussing the author's moral right and equivalent rights recognized in the United States, a conclusion similar to that of Judge Frank was reached. ${ }^{37}$ This writer made the following comment concerning the extent of protection which the "moral right" receives in the courts of those countries where it is recognized: ${ }^{38}$

Much confusion concerning the doctrine has been created by the claim that the moral right is inalienable, whatever may happen to the property aspects of the copyright. Actually, the moral right is inalienable only in the sense that, like all personal rights, it is not capable of transfer by sale or gift. But there is no effective rule of law which prevents an author from waiving one or more of the components of the moral right. While the courts in the "moral right countries" generally do not construe contracts as implying a tacit waiver of the moral right, there seems to be no decision voiding an agreement which expressly and unambiguously waives those personal rights that comprise the moral right. Moreover, in some situations there is a legal presumption of a waiver of the paternity right

${ }^{34}$ See the excellent treatment of this subject in Strauss, The Moral Right of the Author, 40 Ax. J. Comp. L. 506 (1955).

${ }^{35}$ Granz v. Harris, 198 F.2d 585, 590 (2d Cir. 1952).

${ }^{30} \mathrm{Id}$. at 590.

${ }^{37}$ See Strauss, supra note 34 , at 537-38.

"Without using the label 'moral right,' or designations of the components of the moral right, the courts in the United States arrive at much the same results as do European courts. Substantially the same personal rights are upheld, although often under different principles. Also, substantially the same limitations are imposed on these rights, frequently on the same basis. Thus, both here and abroad:

(I) An author has the right to be given credit in the publication, performance, adaptation or other use of his work, but he may waive this right. For some types of publications, such as an author's contribution to a collective work, this right is presumed to be waived unless specifically reserved.

Conversely, an author has the right to restrain the use of his name in a work that is not his, or in a distorted version of his work; but he may waive this right.

(2). An author has the right to prevent prejudicial changes in his work; but he may waive this right. When he authorizes the use of his work in a different medium, he is presumed to have consented to the changes necessary to adapt his work to that medium.

(3) An author cannot be compelled to perform his contract to create a work; but he will be liable in damages for breach of such a contract.

(4). An author has the right to publish his work or to withbold it from publication; but he may assign or license this right.

(5) An author may prevent defamation of character (the 'excessive criticism' of the moral right doctrine), and unfair use or misuse of his work by an action in tort, such as defamation, libel, slander, or unfair competition."

${ }^{38}$ Id. at 537 . 
or of the right to prevent changes which may prejudice the author's professional standing. Thus, in the case of collective works, such as newspapers or encyclopedias, the paternity right, and sometimes the right to prevent changes, is presumed to be waived. Further, in the case of an adaptation of a work for a different medium, such changes as are reasonably required by the medium are held to be authorized.

Akin to invasion of the personal rights of the author is mutilation of his work by burlesque. Such mutilation subjects the writer of the original work to seeing it deliberately deformed for comedy purposes. The objects of burlesque and the types of burlesque are almost illimitable. It may be a play that is satirized by comedy, or a serious musical composition that is popularized or "jazzed up." Generally, the satirist has no license from the original author and justifies his right to mutilate not on the basis of a waiver from the author, but by relying on the so-called "fair use" doctrine, which was developed in connection with statutory copyright. The permissible extent of burlesque was recently before the Supreme Court in the case of Loew's Inc. $v$. $C B S,{ }^{39}$ which involved a Jack Benny television burlesque of the movie Gaslight. In this case, it was held in the United States Court of Appeals that performance of a burlesque on a serious motion picture without permission of the copyright owner was an infringement. However, another federal case holds that burlesque per se is not actionable unless there is sufficient use of the original material to recall the subject matter being burlesqued. ${ }^{40}$ The court indicated, however, that a more extensive use of protectible material may be made in a burlesque than in the creation of another dramatic work.

This problem of burlesque presents a conflict between the concept of a property right and of the author's personal right not to be ridiculed, on the one hand, and, on the other, the importance of the public interest in free expression and free speech. Since the days of Jonathan Swift, it has been well recognized that satire is often the best form of criticism, and certainly the courts do not wish to immunize any writer from criticism. Yet, an opportunity for parody cannot justifiably be made the occasion for wholesale piracy of material. The clash in this regard is reminiscent of that between the interest in the right of privacy on the part of an individual being subjected to cinema or television scrutiny, and the interest of the public in ready access to information. The Supreme Court's affirmance, by an equally divided court, of the lower court's decision furnishes no guideline in this area.

\section{Foreign Law}

As of July 1956 , there were II4 television stations in Europe, of which 14 were in France, $I_{7}$ ( $I_{4}$ BBC, 3 ITA) in Great Britain, 3 in West Germany, and 29 in Italy. ${ }^{41}$ It is worthwhile, therefore, to determine what provision has been made in Europe

\footnotetext{
392 239 F.2d 532 (1956), cert. granted, 353 U.S. 946 (1957). This case has just been decided by the United States Supreme Court, 26 U.S.L. WeEr 3265 (U.S. March 17, 1958).

${ }^{40}$ Columbia Pictures Corp. v. NBC, I37 F. Supp. 348 (S.D. Cal. I955).

${ }^{41}$ E.B.U. Bull., Sept.-Oct. I956, p. 721. For a compact description of station location, facilities, audience, and programming, see The World Market, in I958 Internatronal Television Aluanac 7i6-24.
} 
for the protection of property rights of authors or performers in the burgeoning television industry there. By way of preface, it should be noted that to the present -date, European litigation and legislation have been chiefly concerned with motion pictures; however, many of the principles developed in that context seem significant for television.

\section{x. France}

Unlike the United States, where the producer of a film-whether for theatrical or television use-is usually considered the author ${ }^{42}$ or at least the copyright proprietor thereof, in France there may be an indefinite and frequently undefined number of authors and copyright owners of an individual film. The new French Copyright Law of March Ix, I957, which superseded the Copyright Law of I793, provides that anyone who effectively participated in the intellectual creation of a motion picture is one of its authors. ${ }^{43}$ This would include the scenario writer, the author of the adaptation and the dialogue, the composer of the score, and the rdirector. For a film adapted from an existing work, the author of that work is also considered a joint author of the motion picture. ${ }^{44}$ The producer may be considered an author only if, as a matter of fact, his intellectual contribution justifies this conclusion. ${ }^{45}$ However, the French courts only infrequently take this line, and the Court of Appeals in Paris stated in Blanchar, Honegger and Zimmer v. Société Gaumont" that "the producer, particularly if it is a corporation, governed by a profit-making motive, does not necessarily contribute anything creative."

Under the French view, a copyright has two aspects-the pecuniary or property

42 This fiction occasionally breaks down. Thus, it has been held that, for tax purposes, a motion picture producer would not be treated as an author, and thus he was able to qualify for capital gains treatment on the sale of an inventory of old films to be used on television. In explaining why it was not treating the producer as an author, the court emphasized that the films "involved a multiplicity of skills and abilities, the combined efforts of numerous individuals." Fields v. Commissioner, 189 F.2d 950 (2d Cir. I952).

${ }^{13}$ Art. 14 .

"Ibid.

45 In the case of Société Tobis Sacha v. Studio de l'Etoile, Civ. Trib. Seine, Feb. II, 1935 and March 19, I935, Gaz. Pal. 1935.2.62, and Ct. App. Paris, March 16, 1939, D.H. 1939.263, the French courts did, however, plainly recognize the producer as the author of a film. The decision was based on the Decree of I79I, which granted authors payment for the theatrical performance of their dramatic works; and pursuant to this Decree, the producer was allowed to seize box office receipts of a movie theater which refused to pay the contractual rental for the film. Since the producer was a corporation, the decision, in effect, attributes authorship to a corporation-a result that contrasts with the usual French insistence that an author must be an individual creator.

${ }^{10}$ Gaz. Pal., July 22, 1950, Ct. App. Paris, affirming Civ. Trib. Seine, April 6, 1949, Gaz. Pal. May 21, 1949; see also Prévert and Carne v. Pathé Cinema, Civ. Trib. Seine, April 7, r949, Gaz. Pal, May 1I, 1949; Bénoit-Lévy v. Société de production et exploitation due film "La Mort du Cygne" and Cinéma Péreire Palace, Civ. Trib. Seine, Oct. 24, I941, aff'd, Ct. App. Paris, May 5, 1942, D.A. 1943.80. Sce also Sup. Ct., Dec. 20, 1949, D.x950.73.

The situation in France may be summed up as follows: Anyone who actively participates in creating a motion picture is the author of the part he created. If the producer so participates, he is one of the authors; otherwise, he exercises the rights of copyright owner as assignee of the authors. Whether the is a joint author or merely an assignee of the pecuniary rights depends on the facts in each case. 
right ${ }^{47}$ and the moral right. ${ }^{4 s}$ Apart from the possible claim by a producer to have been an author in instances where his intellectual contribution justifies such a contention, the producer must rely on assignment of all pecuniary rights held by the various persons who have participated in creating the film. On the other hand, the French law prevents his becoming the assignee of the moral right, which is retained by the authors unless they expressly waive it. ${ }^{49}$

In France, acquisition of the pecuniary rights necessary for successful exploitation of a motion picture or a television film involves acquisition of the right to make the film and the right thereafter to exhibit it. ${ }^{50}$ Often these rights are acquired by the producer incident to the employment contract whereunder he hires personnel. For instance, French directors, although considered joint authors of a film, ${ }^{51}$ usually work under an employment contract; and, unless there is a stipulation to the contrary, exploitation rights in the film are automatically transferred by the contract to the producer, the director retaining only his "moral right." Scenario and dialogue writers are, however, usually treated as independent contractors, rather than employees. ${ }^{52}$ Also, where an existing work is to be adapted for motion picture or television use, the contract with the author is usually held to transfer only those rights expressly granted. $^{53}$ Furthermore, composers, if they are members of the Société des Auteurs, Compositeurs et Editeurs de Musique, the French performing rights' society, are exempt from any legal assumption that they have transferred to a producer any performance rights other than those expressly granted..$^{54}$

Although the French theory of joint authorship of films may be theoretically satisfying, in that it recognizes the cooperative creative effort involved in contemporary movie or television productions, it presents almost insuperable practical difficulties. Under the new French law, the rights of each "joint author" do not include prevention of completion and exploitation of a film by refusal to finish a particular part thereof. ${ }^{55}$ Otherwise, legalized blackmail would be the outcome! Nonetheless, the problem of obtaining appropriate releases and licenses where a multiple copyright is involved should not be minimized. Some might infer that better protection would be afforded to all the various "authors" if the copyright were vested in only one of them-whether as trustee for all or otherwise. Certainly it is

\footnotetext{
${ }^{47}$ Under the French law, the "pecuniary" aspects of copyright consist of the right of publication (droit de reproduction) and the right of public representation or performance (droit d'execution publique).

${ }^{48}$ See Strauss, supra note 34 , at 506-20.

${ }^{4} \mathrm{Id}$. at 515-17.

${ }^{\circ 0}$ See note 47 stupra.

${ }^{51}$ Art. I 4.5 of the French Copyright Law of 1957. Plaisant, La Propriéte Littiraire et Artistique, in Extrait du JURis-Classeur Civil Annexes fasc. I7, No. 74 (x953).

${ }^{62}$ Plaisant, supra note 5I, No. 92.

${ }^{63}$ Civ. Trib. Seine, Nov. 24, r934, D.H. 1935.r3; Ct. App. Paris, March 23, 1937, D.H. 1937.239; Civ. Trib. Bordeaux, Jan. 15, I95I, Gaz. Pal. I95I.I.372.

ou Composers are prohibited by their contract with S.A.C.E.M. from transferring performance rights in their music to the producer. See also Art. 17, par. 3, of the French Copyright Law of 1957, which exempts composers from any presumption of assignment of their rights.

${ }^{65}$ Art. 15, French Copyright Law of 1957.
} 
possible that excessive diffusion of interest would diminish the incentive of the individual contributor for protection of the copyright in the corporate work, and it would seem that the producer would be in the best position to enforce this copyright. This reasoning which is expressed in the German draft copyright law of 1954 argues that the producer should be the holder of a unitary copyright. Incidentally, infringement of a multiple copyright inevitably presents difficulties in allocation of damages-difficulties enhanced if less than all the joint authors bring action for infringement.

Despite the obvious solicitude for him by legal theory and practice, the French writer's economic position is, in fact, much less favorable than that of his colleague in the United States, where such doctrines as multiple copyrights and moral right are not expressly recognized. Several factors seem to account for this situation. One is the unsatisfactory financial situation of the French motion picture industry, whereof it was recently noted: "The crisis in which the French film industry finds itself has existed for years; in fact, it has existed ever since the film industry has ceased to be an industry and has become a gamble." Since the cost of film production in France has risen 30-40 times above pre-war cost, while the price of theater admissions has risen only I0-I2 times, any French producer who cannot market his films internationally faces almost inevitable losses. ${ }^{67}$

For the French writer, the conditions under which he bargains in the motion picture industry are not bettered if he seeks work in radio and television. The French radio and television stations are owned and operated by the Government through Radiodiffusion-Télévision Française, which is part of the Ministry of Information and which permits no commercials or commercial programs to be broadcast or telecast over French stations. ${ }^{\text {s8 }}$ The range of French telecasts is normally limited to the borders of the country, for the construction of the television receivers used in France makes them unusable for foreign stations; ${ }^{50}$ and, conversely, foreign receivers are useless for French programs.

Since there are no commercial advertisers, the only purchaser of a television or radio writer's talent is the Government in its capacity as station proprietor and

${ }^{60}$ Comment by M. Charles Méré in Inter-Auteurs 64 (1952). Méré has long been a leader in the International Federation of Authors and Composers. The solution he suggests is a quota system for foreign films like that which exists in Great Britain under the Cinematograph Films Acts, I938 and x948. I \& 2 GEo. 6, c. I7, and II \& I2 Geo. 6, c. 23. The British quotas are regulated by the Board of Trade and approved by resolution of each House of Parliament. For first feature films, the percentage was $45 \%$ in $1948,40 \%$ in 1949 , and $30 \%$ since 1950 . In the case of other films, the quota has been 25\% since 1948. Cinematograph Films (Quotas) Order, I948 (No. 1687); Amendment Orders, r949 (No. 66r) and 1950 (No. 53I). The use of foreign television film is much more in the hands of the Government, since, unlike the motion pictures, English broadcasting is Government-owned-through the $B B C$ and the ITA.

"7 See Méré, sispra note 56.

${ }^{88}$ However, it has been reported that, through a holding company called SOFIRAD, the French Government does have a financial interest in television stations in Monte Carlo, the Saar, and Luxemburg, which stations serve France and yet take the advertising dollar.

${ }^{\text {E0 }}$ Reportedly over a half-million television sets are in use in France. See 1958 IntERnAtional TELEvision Almansc 718-19. 
operator. Apparently this circumstance has not proved beneficial to the quality of French television; one French critic comments that unimaginative and restrictive programming which stemmed from government operation of television has helped the film industry keep what patrons it still has. ${ }^{60}$ Nevertheless, this restrictive policy of RTF has been somewhat alleviated by the fact that RTF has been one of the sponsors, along with BBC, of Eurovision, a network used for eight countries: the United Kingdom, France, Switzerland, the Netherlands, Italy, West Germany, Denmark, and Belgium. ${ }^{01}$

The contrast with conditions in the American entertainment field is striking. Of course, in this country also, the cinema has experienced a considerable decline in the number of pictures produced and the revenues derived therefrom; and so the demand for both writers and performers for movies has probably diminished. Television, however, has taken up much of the slack and has proved a voracious consumer both of story material and of talent. Moreover, in American radio and television, there are a considerable number of large-scale buyers of material and talent, instead of one main purchaser, as in France. In short, the market conditions have been more favorable for the American writer in negotiating for his services than has been the case for his French counterpart.

Another significant circumstance unfavorable to intellectual creators is that the guilds which represent the French writer or performer have generally been weaker than the comparable guilds in the United States in so far as bargaining is concerned. Differences in legislation and economic conditions certainly play a part in such weakness; but there is also the well-known and pronounced orientation of many French guilds and unions towards political as opposed to economic activity. In short, the involvement of the French guilds in extending their main effort toward political maneuvering or even seeking political change-an involvement which, since the days of the "Wobblies," the I.W.W., seems never to have been more than a passing interest of the unions in the United States-has perhaps siphoned off much of the energy that might otherwise have been devoted to collective bargaining. In any event, in France, there is a conspicuous absence of any worthwhile basic collective agreements between authors and the syndicate of film producers.

\section{Germany}

In Germany, the structure of the entertainment industry is somewhat similar to that in France. Under section $\mathrm{I}$ of the Law on Telegraph of $\mathrm{I} 892$, as amended, the right to establish public communications services, including broadcasting, reposes

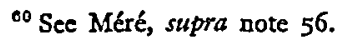

${ }^{01}$ Luxemburg and Monaco both operate on the French system 819 lines. Great Britain operates on 405 , most other countries on 625 lines. If an international program (Eurovision) is transmitted, the procedure is as follows: Picture transmitted in lines of originating country, received by cathode ray tube in central receiving station, re-photographed with studio camera in either or both of the other line systems, then transmitted, by scanning at $8 \times 9,405$, or 625 , as the case may be. There is some degradation involved in this process, but it can be done because all European systems operate in the same field (50), and same frames (25). In the United States, which uses a 60 field, no translation would be possible. 
in the federal government and is delegated to the postmaster-general. Regional delegation of broadcasting operations is also authorized, and, in fact, the German radio and television broadcast service is conducted by several regional government corporations which have been established expressly to conduct broadcasting. Where only one state is involved, such corporations may be created by legislation in that state, as was done, for instance, in Bavaria. Where several states are involved, the corporation can be established by interstate agreement (Staatsvertrag), as was done by four German states in establishing the North German Broadcasting Corporation.

Just as with the British ITA, some commercials are allowed on governmentoperated television in West Germany. However, there is no advertiser control of programs. Consequently, in Germany, as in France, writers and performers in radio and television sell their services and talent to one "buyer," the government corporation operating television.

The German guilds, much like the French, are weak in the entertainment field -with the exception of Gesellschaft für musialische Aufwehrungs-und mechanische Vervielfältigungsrecht (GEMA), which represents composers and is affiliated with ASCAP. Although an organization of German authors was recently formed to obtain royalty payments for public performance of motion pictures which embody an author's works, no success has yet been achieved by this group, and none seems imminent. ${ }^{62}$

In Germany, as elsewhere in Europe, television has advanced to the stage where it presents formidable competition for the cinema. However, German film producers have attempted to defend themselves by prohibiting the showing of films on television. This prohibition at present eliminates in Germany some of the market for writers and performers that might otherwise exist in connection with television. The significance of such a market can be gauged from the report that in April r956, more than half of American television programs were on film and that in 1955, Hollywood made nearly four times as many television films as it made films for distribution to theaters. ${ }^{\text {B }}$

In light of the economic realities in the German entertainment industry, the position of writers or performers would be inferior to their counterparts in the United States, regardless of their position in the courts.

In so far as an author's copyright is concerned, the statutes governing today were originally enacted in IgOr and 1907 and amended in rgro to include motion pictures. $^{64}$ Movies were considered only a series of photographs, and so they were granted protection as such under the law concerning photographic works. How-

${ }^{69}$ This organization is the GELU, with offices in Hanover, Germany. See Film und Recht No. $r$, I957, p. 12. Actually, the GELU seems to have soft-pedalled for the present the demand for royalty payments.

1956.

${ }^{82}$ According to a report by Television Programs of America, Inc., which is cited in Variety, April 25,

oi Copyright Law in Literary and Music Works of 1901, LUG $\$$ 12, second par., 6 Copyright Law on Works of Art and Photographs of 1907, KUG § 15 a. 
ever, because this protection proved far too narrow, it is generally admitted that the law on copyright in literary and musical works also applies to motion pictures. ${ }^{65}$

The German copyright laws in the case of motion pictures do not define the author $^{86}$ and thus create the same problem of film authorship which is encountered in the French law. Thus, in West Germany, the following may be film authors: the writer of the script, the writer of the scenario, the composer of the music, the director (if he makes any original and creative changes in the existing material), ${ }^{67}$ and even the cameraman with respect to the photography. ${ }^{68}$ The producer is generally not deemed an author unless he is active in a creative manner; but he may acquire copyright in the various contributions to a film by contract with the respective authors. $^{69}$ Of course, the components of the moral right which are recognized by the law and courts remain with the author. ${ }^{70}$

The German Draft Copyright Law of $1954^{71}$ proposes radical changes in the concept of film authorship and in the scope of transfer of the right to make a film. Section 93 of the Draft provides, in a manner almost reminiscent of the American Copyright $\mathrm{Act}^{72}$ that the owner of the establishment which makes a film shall be deemed its author. Section 92, which authorizes transfer of the right to make a motion picture, raises a legal presumption that transfer of the right to make a motion picture is also a transfer of the right to reproduce and distribute it, perform it publicly, broadcast it, translate or further adapt it, and to use such adaptation. Naturally, the German authors have strenuously objected to these sections of the Draft Copyright Law.

In explaining the switch from multiple authorship to the fiction of a single authorship of films, the proponents of the Draft commented $:^{73}$

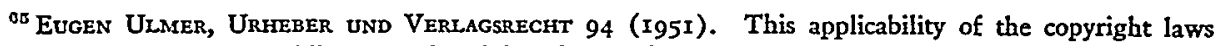
to motion pictures is in addition to the right of reproduction by motion picture which is granted to the author of an existing work. LUG $\$ \mathrm{I} 2$, second par., 6 .

${ }^{\circ 0}$ LUG $\S 2$; KUG $\S \mathrm{x}$.

${ }^{07}$ VoIGtLaENDER-Elster-KI.EINe, URheberrecht 95 (I952). See also West German Sup. Ct., I952, 5 Entscheidungen des Bundesgerichtshefes in Zivilsachen [B.G.H.Z.] Ir6.

${ }^{08}$ KUG § I; West German Sup. Ct., 1953, G.R.U.R. 299.

${ }^{\circ}$ ULMER, op. cit. sttpra note 65 , at 132 . Such contracts may transfer the exclusive or non-exclusive right to make the motion picture, and they may limit this right to specified territories. Id. at 289 . Usually the contract includes the rights both to make the film and to exhibit it. Just as in France with the members of the S.A.C.E.M., the composers come under different arrangements, the royalties for use of their film music ustally being collected for them by the composers' organization, GEMA. The assignment of the rights of the author may be tacit where there is an employer-employee relationship. Id. at 132 .

${ }^{70}$ ULMER, op. cit. supra note 65 , at 289 .

${ }^{71}$ This Draft, together with an experts' report, was published on March 15, 1954, by the West German Ministry of Justice.

${ }^{73} 61$ StaT. 652 (1947), i7 U.S.C. \& 26 (1952).

${ }^{78}$ Sec page 218 of the experts' report, supra note $7 x$. The Draft Copyright Law distinguishes between the copyright in works used in making a picture, copyright in the picture itself, and the "related" rights of those artists who perform in the picture. The works used in making a picture include any existing works which have been adapted for the film, the scenario, and the film music. Authors of these works are not deemed authors of the motion picture because "the motion picture is different from, and more than, a reproduction of the works used in the motion picture." Ibid. 
Copyright in a motion picture could vest in the persons who participated in creating the motion picture itself. . . . The most obvious answer would be to consider as authors those people who created the work. . . . That may be the director, the performers, the cutter, the director of lighting effects, the stage designer, the producer and others. . . . Frequently these persons themselves do not know the exact extent of their creative contribution. This would make it very difficult, if not impossible, to determine the scope of their copyright.

Thus, because of the uncertainty created by giving individual copyrights to all creators, and in order to protect the producer, the general principle is abandoned that only an actual creator can be an author and copyright owner. Instead, a legal fiction is substituted whereby the producer is considered the author of the film, even though his creativity may, in fact, be reflected only in the payment of production costs. Of course, in many instances, the writers, performers, and other creators of a motion picture would not suffer from such a solution since, in connection with a contract of employment or otherwise, they would be considered to have assigned to the producer all rights of exploitation of the film. On the other hand, in connection with the theoretically inalienable "moral right" of the author, it might make quite a difference whether-by legal fiction or otherwise-the producer is considered the sole author of a movie or, instead, all the creators of the picture are considered to have been its authors. ${ }^{74}$

The fiction proposed by the German Draft Copyright Law of treating the pro. ducer of a motion picture as its sole author is a step in the direction of satisfying the claims of European producers; but it is not all to which they believe themselves entitled. The International Federation of Film Producers has pointed out that, in its opinion, the producer is in fact the creator of a motion picture and is only assisted by the author of the scenario, the composer of the music, and the director. ${ }^{75}$ This view places copyright in a producer not because of any expedient legal fiction, but because he is held to be the real author.

The presumption in section 92 of the Draft concerning the transfer of rights to a producer is not a conclusive one and can be negated or limited by contract. Thus, television or translation rights can be retained by an author or composer. On the other hand, under section 92, the rights to make a motion picture, to distribute copies thereof, and to exhibit it publicly must be transferred together. ${ }^{70}$

The German movie industry employs five types of basic contracts with authors-

${ }^{74}$ The moral right of the director is preserved in section 96 of the Draft Law. The loss of the moral right of the other persons who participate in making a film is discussed at page 221 of the experts' report, stipra note 7I, and the conclusion is reached that this loss is far outweighed by the need to avoid atomization of the copyright. See also Runge, Das Gruppenwerk als Object urheberrechtlichen Schutzes, I956, G.R.U.R. 407.

${ }^{75}$ See Memorandum of the Federation, in Le Drort D'AUTEUR 45 (1954). Compare the vicws of the International Literary and Artistic Association, the International Federation of Film Authors, and the European Radio Union at pages $28,6 \mathrm{r}$, and $8 \mathrm{r}$, respectively, in that same publication.

${ }^{78}$ This section makes a concession to composers by permitting them to demand payment of royalties for public showing of a motion picture containing their music. It should be observed that, throughout Europe, the composers' organizations are among the most effective in obtaining benefits for their members. Many of them are affliated in one way or another with the Amcrican ASCAP. 
and presumably the contractual pattern in radio and television there will follow similar lines. These five types are: ( $\mathrm{r}$ ) sales contracts for sale of an existing literary work (Verfilmungsvertrag); (2) contract for adaptation of an existing work or creation of a new film manuscript (Filmmanuskriptvertrag); (3) contract to create a scenario (Filmdrehbuchvertrag); (4) contract to compose music for a film (Filmmusikvertrag); and (5) contract for employment of screenwriters (Anstellungsvertrag für Filmschaffende). The employment contract merely regulates the pay scale and the obligations of the employee. The others, all very much alike in terms, contain detailed provisions for the assignment of authors' rights to the producers; and they reveal the disparity of bargaining position as between producer and author in contemporary West Germany.

Under the typical authors' contract, an author assigns to the producer world film rights and subsidiary rights such as: (a) to use all or part of the work for the production of a motion picture in German or any other language; (b) to make any changes in the film and to "dub" in any subtitles or dialogue; (c) to reproduce, distribute, and exhibit the film in any country; (d) to broadcast all or part of the film or the soundtrack thereof on radio or television, and to permit the reception of such broadcasts in public places; (e) to use the title; and (f) to give brief descriptions of the work in newspapers or broadcasts for purposes of advertising the film.

The contracts expressly exclude the right of the author to assign or license to a performing rights' society any right in or connected with the public performance of the film. However, this exclusion is absent from the film music contract because the composers have their own strong organization, GEMA. The standard contract excludes also the right of the author to use his work in any other literary form without consent of the producer; but this consent may be refused only where such use would clearly be detrimental to the exploitation of the film. ${ }^{77}$ The producer has a free hand in changing the work in the course of producing the film, and the author has no right to damages if the film is not produced within the agreed time, or not produced at all. The author has a right to a screen credit only when the individual contract between him and the producer expressly provides therefor; and this principle holds true even for the composer of the film music.

Significantly, the film contracts are closely modeled on the provisions of the Tarifordnung, a decree which created a standard contract for film artists and cameramen. Although the Tarifordnung was promulgated during Nazi days, on August 19, 1943, it still appears to be in effect as to performers; and, as just noted, it sets the pattern for the German author as well. The present vitality of this

${ }^{77}$ Unless there is a specific agreement to the contrary, film rights are assigned without limitation as to territory, time, or contents. This principle, at least as to absence of time limitations, should be contrasted with the American view that circumstances sustaining the transfer of the right to a renewal copyright must be stronger than those required to sustain the transfer of the original copyright, since the right of renewal is separate from the original copyright. Shapiro, Bernstein \& Co. v. Bryan, 123 F.2d 697, 700 (2d Cir. 194I); Rossiter v. Vogel, I34 F.2d 908, 9xo (2d Cir. I943). 
decree is probably another good indication of the weakness of the guilds in West Germany in so far as the entertainment industry is concerned.

As if to emphasize the weak position of the German screen or television writer, the Landgericht of Hamburg held, on October $12,1955,{ }^{78}$ that a written declaration by a scenario writer that he transferred to a producer "copyrights of all kinds" would exclude any reservation of book publication or serial rights. One reason given by the court for not implying a reservation was the express assignment by the author of radio broadcasting rights. Since broadcasting and publication in printed form of the subject matter would help attract a larger audience to the film and thus assure its commercial success, the producer was deemed to have a considerable stake in those rights, and the assignment of the broadcasting rights was deemed to carry the publication rights as well. If this decision is symptomatic, the German author will receive a less favorable interpretation of his contract with a producer than authors in France or in the United States.

3. Italy

In Italy, broadcasting is in the hands of a government corporation, Radio Television Italiana (RAI). Like the British ITA, this corporation has some commercial telecasting, but no live commercials are allowed. Besides commercials, license fees on receivers and taxes on sales of equipment furnish revenues to sustain broadcasting.

As to film rights, the Italian Copyright Law of I94I takes a position between that of France, where all contributors are considered joint authors, and that of the United States and of the proposed German Draft Copyright Law, where the producer is deemed the sole author of the film. Under article 44 of the Italian Law, the authors of the story and the scenario, the composer of the music, and the artistic director are joint authors; but articles 45 and 46 grant to the producer the economic exploitation of a film. This right to exploit does not, however, include any right to make further adaptations or translations unless there is an agreement to that effect, and the composers and lyricists are entitled to royalties for public exhibition of the motion picture. $^{79}$ The other authors-that is, the writers of the story and of the scenario, and the director, in the absence of any agreement to the contrary, are entitled to additional payment from the producer when the receipts have reached a stipulated level, provided these persons under their contract receive no percentage of the box receipts. ${ }^{80}$ Authors of the literary or musical parts of a motion picture may reproduce and use their contributions separately, so long as there is no interference with the rights of the producer. ${ }^{81}$ Documentary films are relegated by the Italian Copyright Law to protection as photographs, which normally means that their term of protection is twenty years. ${ }^{82}$ Copyright in a documentary film may, under an employment contract, belong entirely to the employer. ${ }^{83}$

${ }^{78}$ This decision has become final.

${ }^{80}$ Art. 46, par. 4 .

${ }^{83}$ Art. 92.
${ }^{70}$ Art. 46, pars. 2, 3.

${ }^{81}$ Art. 49.

${ }^{83}$ Art. 88. 
Some definite advantages seem to inhere in the Italian legislation. For one thing, by recognizing authorship in several persons, it avoids the possibility of destroying the moral right of all but the producer-who sometimes is the one who has contributed to the film the fewest of those intangible values with which the moral right doctrine is so inextricably intertwined. At the same time, however, the Italians avoid the dangers of atomization implicit in the multiple authorship approach by limiting the basic right of exploitation to a single person, the producer. The producer's right of exploitation is, in turn, subjected to certain limitations which will allow the retention by the several authors of residual rights separable from the exploitation of the film itself-among them the right to adapt the author's original work for some other media such as television. Also, Italy seems committed to the view that all "authors" should be entitled to some percentage of the gross receipts arising from their work. All in all, Italy provides a milieu in which writers for motion pictures or for television seem relatively well-situated to share in any revenues arising from their creativity.

\section{Great Britain}

The British entertainment industry reveals several patterns of ownership and operation. Motion pictures are produced by independent producers-upon whom, however, the Government has a substantial impact through exchange controls, quotas, $^{84}$ and the like. Government-owned and operated, the British Broadcasting Corporation, BBC, has both radio and television facilities and is completely noncommercial. The more recently established. Independent Television Authority, ITA, discussed elsewhere in this symposium by Professor Lloyd, is an agency of the Government, subject to the control of the Postmaster-General. In accord with the legislation which established it, ITA allows private programming contractors to utilize its television facilities, and these contractors, in turn, sell time to advertisers for commercials. However, since no program sponsorship is permitted, there is no advertiser control.

In the competition between BBC and ITA, the latter seems to have made substantial headway, so that a recent report indicates that seventy to ninety per cent of the British television audience now watches ITA. ${ }^{85}$ Indeed, it was observed only a year ago: ${ }^{80}$

In the past year BBC-TV have shown some concern at the way they've been overtaken in the popularity Derby (by the ITA stations) and their programming shows signs of being conditioned to meet this situation. As of the first of the year, they begin to operate their new agreement with the motion picture industry for the release of 20 features a year, of which 12 will be English-speaking from either Britain or Hollywood.

The competition between the two networks, even though both are governmentcontrolled, has caused production costs for television to shoot up in England and, at

\footnotetext{
84 As to quotas, see note 56 supra.

${ }^{85} \mathrm{Sec}$ Billboard, Aug. 12, 1957.

${ }^{80}$ Variety, Jan. 9, 1957.
} 
the same time, has improved the bargaining position of the English author or performer. Furthermore, the English labor organizations are more oriented than some of their Continental counterparts to the achievement of economic, as distinguished from political, objectives, and, thus, in the entertainment industry, have been able to achieve for their members the protection of relatively favorable collective agreements. In short, even though English law, like that in the United States, may not offer the theoretical protection to authors and performers that is granted in some Continental countries, any lack of legal protection is more than offset by the superior bargaining position of authors and performers vis-à-vis producers in both Great Britain and the United States.

It is worth noting, also, that unlike West Germany, where filmed programs are kept off television, English television has relied heavily on film, including reruns of American serial shows like Dragnet. Consequently, the law evolved in England for motion pictures is especially important with respect to the television industry.

The fundamental source of protection for those persons who create an English film is the Copyright Act. As a consequence of the 1948 Brussels Revision of the Berne Copyright Convention, Great Britain in $195^{87}$ replaced the Copyright Act of I9II. ${ }^{88}$ Under the old Act, the rules on status of motion pictures were rather confusing, although Great Britain did have a unitary view of the copyright. A film might have two aspects: In the first place, it was deemed a series of photographs, and, thus, in the category of artistic work; ${ }^{80}$ if the arrangement or acting form, or the combination of incidents, gave it an original character, the motion picture was also a dramatic work. ${ }^{30}$ This dual nature led to difficulties concerning ownership and duration of copyright-both of which differed as between dramatic and artistic works. ${ }^{91}$ Filmed telecasts presented identical problems, and arguably even a live telecast would have been considered to involve a photographic as well as a dramatic work.

Section ${ }_{3}$ (ro) of the Copyright Act, I956, defines "cinematograph film" as "any sequence of visual images recorded on material of any description (whether translucent or not) so as to be capable... (a) of being shown as a moving picture, or (b) of being recorded on other material ... by the use of which it can be so shown." Copyright subsists in every motion picture "of which the maker was a qualified person for the whole or a substantial part of the period during which the film was made." 92 The "maker" of a motion picture is defined as the "person by whom the arrangements necessary for the making of the film are undertaken,"

${ }^{87}$ Copyright Act, 1956, 4 \& 5 Eliz. 2, c. 74.
${ }^{80}$ Id. $\S 35(\mathrm{I})$.

${ }^{21}$ For details on term of protection and copyright ownership, see Walter A. Copinger, The Law of Copyright (8th ed., James r948); William J. Leaper, Copyright and Performing Rigirts (I957); John P. Eddy, The Law of Copyrigrt (1957).

${ }^{92}$ Copyright Act, 1956, 4 \& 5 Exrz. 2, c. 74, $\$$ I3(r).

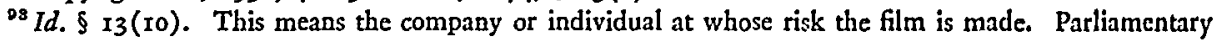
Debates, House of Commons, Standing Committee B, Official Report (Lords) on Copyright Bill, at 306 , 3I3. 
"qualified" " refers to individuals who are British nationals or resident in the United Kingdom or in a country to which the British Copyright Act has been extended by Order in Council. ${ }^{95}$ Copyright in a film vests in such a maker, ${ }^{96}$ who has the right to prohibit the following acts: "(a) making a copy of the film; (b) causing the film, in so far as it consists of visual images, to be seen in public, or, in so far as it consists of sounds, to be heard in public; (c) broadcasting the film; (d) causing the film to be transmitted to subscribers to a diffusion service." 97

After copyright in the motion picture expires, a public exhibition of it does not infringe the copyright subsisting in any literary, dramatic, musical, or artistic work which forms part of the film, ${ }^{98}$ and this despite the fact that the performance may take place before the expiration of fifty years after the death of the author or composer of the original work. Sound tracks are included in the definition of "cinematograph film."99

Otherwise, the copyright in a motion picture does not affect copyright in any original work from which the motion picture is made and is additional to, and independent of, any copyright subsisting in such original work. ${ }^{100}$ However, showing a film after copyright of the original work has expired does not infringe that copyright; ${ }^{101}$ and, therefore, the author of the original work cannot demand royalty payments for such showings of the film.

Section 40 of the Copyright Act of 1956 contains two more exceptions to the exclusive rights of the copyright owners of a motion picture. Under section $40(2)$, the reception of an authorized broadcast of a film in a public place is considered a licensed public performance. Section $40(3)$ has an identical provision for a reception over diffusion service. No infringement suit lies against the person who shows the film in public, but the public showing is considered in assessing damages in an infringement proceeding against the broadcaster. The definition of "cinematograph film" appears to cover almost any type of device the engineers may devise for recording visual or acoustic performances for later television use. ${ }^{102}$ With increasing emphasis throughout the world on the use of such recordings and with the present heavy British use of filmed American telecasts, the new Copyright Act will have great impact on Great Britain's television industry. ${ }^{103}$

${ }^{04} I d . \$ 55(\mathrm{a}), \mathrm{I}(5)(\mathrm{b})$.

${ }^{\circ 0} \mathrm{Id} . \S \mathrm{I} 3(4)$.

${ }^{08}$ Id. $\S \mathrm{I} 3(7)$.

${ }^{200} 7 d$. $\S 16(6)$.

${ }^{202} I d . \S 13(10)$.

${ }^{103}$ Although the scope of this article does not permit extended analysis of the copyright laws of many nations, it is interesting to look briefly to Latin America and to the Orient. In Argentina, the author of the plot and the producer are considered co-authors of a motion picture; and in the case of a musical film, the composer has the same rights as the author of the plot and the producer. Copyright Law of I933, art. 20. Unless there is a special agreement, the producer may exhibit a film without the consent of the author of its plot or the composer, but they are entitled to royalties. Id. art. 2r. The author of the plot has the right to publish his contribution separately or transform it into another work, and so, too, with the composer. Ibid. Interestingly, the names of the following persons must be mentioned at each showing of the film: producer, author of scenario or plot, authors of the original work from which the 


\section{E. International Conventions}

The revised Berne Convention in Article $14^{\mathbf{1 0 4}}$ recognizes two kinds of protection regarding a motion picture. In the first place, authors of existing literary, scientific, or artistic work have the right to authorize (or prohibit) adaptation and reproduction of their work as a motion picture and to control distribution and presentation thereof. Secondly, motion pictures are protected as original copyrightable works. Yet, there is no mention in the Convention of the author of the motion picture itself. This peculiarity is explained by the divergent treatment given motion picture authorship in the member countries of the Berne Union which has made a uniform provision impossible.

The Belgian Government and the Berne Bureau, which together prepared the program for the 1948 Brussels Conference, proposed to give copyright to the authors of a motion picture, ${ }^{105}$ but they did not specifiy who these authors were. The French Government also wanted copyright to be given to "the authors of motion pictures,"106 while the British proposed to vest copyright in "the proprietor of the original negative or similar vehicle from which a motion picture may directly or indirectly be manufactured."107

The Italian Government shied away from the clash between the French and British proposals. Instead, Italy's chief concern was with the following provisions: "In every public presentation of a motion picture there must be an indication of the place of production, of the name of the producer, the composer of the music, the author of the scenario, the director, and the principal actors. ... These indications shall not by themselves determine whether the indicated persons are copyright proprietors of the film or may be considered joint owners." Italy was willing to unify authorship for procedural purposes alone, by a provision that "the producer whose name appears on the film is presumed to be entitled to bring action against third parties in regard to film."108

The report of the Brussels subcommittee on photographs and motion pictures

plot was taken, composer, artistic director or adapter, and the principal performers. 1d. art. 22. Thus, certain persons have a statutory right to credits in Argentina.

In Japan, there is a great deal of room for interpretation. The author of a work of literature, science, or art has the right to reproduce his work by means of a motion picture, but the person who has repro. duced another's work by means of a movie is deemed the author of the film. Japanese Copyright Law of 1899 , as amended art. 22 . The producer's right is not allowed to prejudice that of the original author. Ibid. Copyright in a work produced by collaboration of several persons belongs to authors jointly. Id. art. 13. Who, then, are the authors of a motion picture? Japanese law contains a provision that, in cases where contributions of the several authors are inseparable and one of the authors refuses publication or public performance, the others may acquire his share upon payment of an indemnity. 1d. art. I3, second par.

${ }^{104}$ This article was first included in the convention at the Revision Conference held in Berlin in 1908, and was revised at Rome (1928) and Brussels (1948).

${ }^{106}$ Actes de la Conférence de Bruxelles 347 (1948).

${ }^{100}$ Id. at 354 .

${ }^{107}$ Id. at 355 .

${ }^{108}$ Ibid. 
stated tersely that it was impossible to define the author of a motion picture. ${ }^{109}$ The Rapporteur Général at Brussels remarked with resignation that differences of opinion during the Berne Revision Conference made it necessary to avoid proposing a statement of the legal nature of a motion picture. ${ }^{110}$

Other international conventions have been equally unsuccessful in this area. The Havana ${ }^{111}$ and Washington ${ }^{112}$ Conventions contained provisions which protect motion pictures as original works, but, like the Berne Convention, they do not state who the protected person is. The Universal Copyright Convention explicitly recognizes the principle of "national treatment"-i.e., works of nationals of contracting countries must be protected in each other contracting country in the same manner as the other country's nationals are protected. ${ }^{113}$ The Buenos Aires Convention of Igro makes no mention of motion pictures except to list photographic works, ${ }^{114}$ but the legislative history of this provision and the reasoning of at least one case leads to the conclusion that this Convention does not affect motion picture rights. ${ }^{115}$

In so far as the international conventions are concerned, the televising of an existing motion picture is confronted with the same uncertainty as to authorship that exists for other types of exhibition of the film. However, article II-bis of the Berne Convention does reserve to an author the exclusive right of authorizing, broadcasting, and telecasting his work. This article does not apply, however, if a work is specially filmed for showing on television, since the telecast is not merely a "communication thereof to the public" within the meaning of article Ir-bis. ${ }^{116}$ Instead, the telecast of the film in this event involves a public performance (or under some laws, even a publication) of a new work. Of course, problems may arise where the film, although made especially for television, is subsequently rerun on television. Does it then lose its character as the public performance of a new work? And certainly, too, as to live television, the inability to reach international agreement on authorship should prove as evident as with respect to motion pictures.

${ }^{100} \mathrm{Id}$. at 358 . See also report of the Rapporteur Général. Id. at I03. Of course, the provisions in article 2 that motion pictures are copyrightable and that the copyright operates for the benefit of the author does not solve the question of who is the author. And under the Berne-Brussels Convention, is it only the author of an existing work rather than one who writes a scenario for a film who gets protection?

${ }^{110} I d$. at 103d, 104 .

${ }^{111}$ See art. 2 thereof, which, incidentally, was not ratified by the United States.

${ }_{112}^{12}$ See art. III thereof, also not ratified by the United States.

${ }^{118}$ See art. II of this Convention. Since the standard of protection is relegated to the domestic laws of the contracting countries, the divergent protection granted movies in various countries created no difficulty.

114 The catch-all phrase at the end of art. 2 that "all productions that can be published by any means of impression or reproduction" are included in the expression "literary and artistic works" may be interpreted to include motion pictures.

${ }^{115}$ See Todamerica Musica, Ltda. v. RCA, $17 \times$ F.2d 369 (2d Cir. I948). See also Thorvard Solbero, The Development of International Copyright Relations Between the United States AND Foreign Countries I5 (1933).

110 The rules of art. I4 instead of art. II-bis seem to apply. 
III

\section{Performlers' Rights}

\section{A. Contractual Rights}

Just as the international organization of European film producers maintains that a producer is an author because he "creates" a film, it is possible to argue that a performer is the sole "author" of his own performance. It has been held, however, in Capital Records v. Mercury Records Corp. ${ }^{117}$ that a performance cannot be copyrighted under the American statutory scheme, even though in that case the Second Circuit Court seemed to acknowledge the right of Congress to amend the Copyright Act to encompass performances within its protection. Since no legislative change of this sort appears to be in sight, performers presumably will seek to approximate copyright protection by means of collective bargaining agreements and by court tests of their common-law rights under the laws of the various states.

The success of performers in obtaining payments for residual rights in the telecasting of old films shows the effectiveness of the collective-bargaining tool. ${ }^{118}$ Also, several recent decisions attest the judicial ferment in this area of the common law.

A federal court of appeals recently commented that today it is usual to provide specifically by contract between performer and entrepreneur as to what uses the product-such as a motion picture-may be put and that, therefore, as to performances of films created in the future, the question of a performer's rights in his performance would become largely academic. ${ }^{119}$ Even if this prognosis is correct, the issue remains very much alive with respect to performer-producer film contracts entered into before motion pictures became an important staple of television fare and which do not reflect such use.

Cases involving two celluloid cowboys, Roy Rogers and Gene Autry, ${ }^{120}$ led to an analysis by the courts of performers' rights in light of actor-producer contractual provisions. ${ }^{121}$ In the Rogers case, the pertinent facts were briefly as follows: Under the

$$
{ }^{217} 221 \text { F.2d 657, 660-62 (2d Cir. 1955). }
$$

118 For a general discussion of residual rights, see the article by Gilbert, elsewhere in this symposium.

${ }^{110}$ Ettore v. Philco Television Broadcasting Corp., 229 F.2d 48x, 487 (3d Cir.), cert. denied, 351 U.S. 926 (1956). The case is discussed by Nimmer, Recent Trends in the Law of Artistic Property, 4 U.C.L.A. L. REv. 323, 336 (r957), and Note, 10 Rutgers L. REv. 741 (1956). In connection with the Ettore case, it should be noted that if a boxer is a performer, so are most of the persons who "participate" in television shows. The popular TV quiz shows and the many audience participation shows actually employ thousands of persons who may never think of themselves as performers with performers' rights until they see or hear of some other unrelated use being made of their performances. In addition, there are the same shows in which professional actors play TV games which could easily be put to other uses. Nothwithstanding the court's prediction, it is not improbable that, quite aside from the problems of the diminishing number of old films like the Ettore-Louis fight pictures, the contracts for which contained no reference to TV, there may still be many problems with other uses of television films. Sce Redmond v. Columbia Pictures, Inc., 277 N.Y. 707, 14 N.E.2d 636 (1938).

${ }^{120}$ Republic Pictures Corp. v. Rogers, 213 F.2d 662 (9th Cir. 1954); Republic Productions v. Rogers, 213 F.2d 667 (9th Cir. 1954); Autry v. Republic Productions, 213 F.2d 667 (gth Cir. 1954). See also Wexley v. KTTV, I08 F. Supp. 558 (S.D. Cal. 1952), $a f f d, 220$ F.2d 438 (9th Cir. 1955).

${ }^{12 x}$ See Silverberg, Televising Old Films-Some New Questions About Performers' and Proprietors' Rights, 38 VA. L. REv. 615 (1952). At that time, in evaluating the case, I concluded: "Further judicial 
contracts of 1937 and 1948 between Rogers and Republic, Rogers had granted to the producer the exclusive right "to photograph and/or otherwise reproduce any and all of his acts, poses, plays and appearances." The performer also granted to the producer "all rights of every kind and character whatsoever in and to all such photographs, reproductions and recordings and all other results and proceeds of his services hereunder, perpetually ....," and further, the use of his name, likeness, and voice for advertising, commercial, and publicity purposes. However, the artist reserved to himself the right to "commercial tie-ups."

The Ninth Circuit Court held that under the contracts, the terms "acts, poses, plays and appearances" did not mean the same thing as "name, voice and likeness," and that, therefore, "acts, poses, plays and appearances" referred to the activities of the artist in connection with the motion picture, whereas "name, voice and likeness" had reference to non-motion picture reproductions of characteristics of the performer. The court held that restrictions upon the use of the actor's name, voice, and likeness did not preclude the use of his acts, poses, plays, and appearances and that, therefore, the producer could license the use on television of the motion picture in which the performer appeared. The court further held that, in view of the express contractual consent by the performer to the proposed use by the producer, the licensing of television rights was not unfair competition.

In the Autry case, also, the contract was interpreted as distinguishing between use of the performer's voice, name, and likeness and his activities in the motion picture as such. The court concluded that the performer had granted all rights in his motion picture activities to the producer. In this case, the question was broader than in the Rogers case because the use of the motion picture on television in the Autry case involved cutting the films in order to accommodate commercials, and it was contended that in so doing, the producer might so alter or emasculate the motion pictures as to render them substantially different from the work which the artist had originally produced. Further, Autry also contended that the exhibition of an old picture showing the performer in outmoded clothes and automobiles: could be quite harmful to his reputation. As to the performer's right to guard his reputation in this manner, the court tersely stated that the contractual consent extended to the risk of having the motion pictures exhibited when the fashions and cars shown therein were no longer in fashion. As to the question of "emasculating" the films the court found that the actual cutting to 53 minutes was within the contractual agreement and that complaints about any abuse in this respect should be presented if and when the occasion arose. Here also, the court precluded recovery upon the ground of consent, although the possibility that, under different circum-

thought may create a new jural concept, to wit, that the product of an artist's labor is a thing of economic value, and that its use in a new and additional medium warrants additional compensation. However, in the present state of the law the actor must look for his protection to his contract, legislation, or collective bargaining." $I d$. at 65 . 
stances, there might be an invasion of the performers' personality was not ruled out.

The decisions of the Ninth Circuit Court in the Rogers and Autry cases did not deny or affirm the performers' property rights in their performances; but by interpreting a general clause in the respective contracts as assignments of television rights, they effectively excluded the performers from participation in the profitable televising of old motion pictures.

Both Autry and Rogers argued that licensing the motion pictures for television without their consent constituted unfair competition, and in both cases, the court held that the contractual consent to any use of the film included such exhibition and precluded a claim of unfair competition.

Ettore v. Philco Television Broadcasting Corp. ${ }^{122}$ concerned the effort of an expugilist to recover damages from a broadcaster for unauthorized telecasting of a film depicting his boxing bout with Joe Louis. The plaintiff's contention was that he had not sold his television rights in motion picture of the fight and that, therefore, unauthorized televising of his performance was unfair competition. Although this bout took place and the contract had been made before the advent of commercial television, the Third Circuit Court held that Ettore could recover damages on the theory of unfair competition because the unauthorized telecast constituted injury to a property right. In its treatment of the effect of the sale of movie rights, the Ettore holding is diametrically opposed to the Autry and Rogers cases. Because so many movie producers are releasing their old films in ever greater numbers for showing on television, this issue is of vital importance to the older generation of cinema actors who are receiving no portion of the television revenues for their old movies.

As an interesting sidelight, under a contract concluded in 1948 between the American Federation of Musicians and the major Hollywood studios, old film cannot be sold to outlets other than theaters without recourse to the AFM. Under this contract, the AFM is apparently entitled to a rerecording fee of $\$ 25.00$ per musician employed in scoring the film, plus five per cent of the gross from television sales. However, to escape the financial burden of the payments required under this agreement, Republic Productions has commenced an antitrust suit against the AFM. ${ }^{123}$ This suit may ultimately determine the extent to which a union can control the

${ }^{122} 229$ F.2d $48 \mathrm{r}$ (3d Cir.), cert. denied, 35I U.S. 926 (1956). In Granz v. Harris, r98 F.2d 585 (2d Cir. 1952), a presentation of abbreviated versions of a performer's work was held to be unfair competition and an invasion of his personal rights. Also see Fairbanks v. Winik, 1x9 Mise. 809, 198 N.Y. Supp. 299 (Sup. Ct. I922), rev'd, 206 App. Div. 449, 201 N.Y. Supp. 487 (Ist Dep't I923). But see Lillie v. Warner Bros. Pictures, Inc., 139 Cal. App. 724, 34 P.2d 835 (1934).

${ }^{123}$ It is reported in Billboard, March 30, 1957, that the Superior Court in Los Angeles held in a suit by Telemount Pictures against Screen Actors Guild that residual payments for a telcrision series did not violate the antitrust laws. Also, members of the Hollywood AFM local have brought an action sceking damages of $\$ 2,100,000$ from the AFM, trustees of the residual payments trust fund, and the telcvision film producers, and asking also that television film producers, networks, and distributors be enjoined from making further payments to the trust fund. See Billboard, May 6, 1957. 
television use of theatrical films by means of collective bargaining agreements entered into subsequent to the completion of the films and independent of the contracts in force when the film was made.

\section{B. Property Rights}

Apart from contractual rights, the protection of a performer against unauthorized use of his performance is usually based on one or more of three common-law doctrines: literary property rights, unfair competition, and, less frequently, the right of privacy (now being supplemented by the right of publicity). A leading case in the field until recently was $R C A$ Manufacturing Co. v. Whiteman, ${ }^{124}$ where the Second Circuit Court stated that common-law rights, if any existed in the recorded performance of a musical artist, ended with the sale of the records. However, this holding, on which numerous other decisions have been based, was expressly overruled in Capital Records v. Mercury Records Corp., with the effect that-at least in New York-musical artists, or other originators of a recorded performance or their assignees, do have a common-law property right in their records even after the sale thereof.

Admittedly, the Capital Records case turned largely on the question whether the plaintiff had lost its exclusive right to reproduce and sell its records by putting them on public sale-i.e., whether public sale of records amounted to "common-law publication" and thereby caused a forfeiture of the common-law property right. Nonetheless, the Third Circuit Court in the Ettore case used Capitol Records for the proposition that ${ }^{125}$.

if the performers' rights had not been totally yielded by them, the exploitation of their performances by reproductions without further compensation would have been enjoined or prohibited under the guise of protection from unfair competition.

Thus, even though the performance of a pugilist may not be an intellectual creation and so not entitled to protection by common-law literary property rights, Ettore, on the basis of an analogy, had a cause of action in unfair competition.

A fact situation, identical to Ettore, was presented in Sharkey $v . N B C,{ }^{126}$ where sections $5^{\circ}$ and 5 I of the New York Civil Rights Law were the sole basis for the court's granting relief to the plaintiff. There the court held that ${ }^{127}$

use of plaintiff's name and the moving picture made them less valuable to plaintiff ... stated a cause of action and that defendant did not show that plaintiff had lost or so far restricted his right of privacy as to be without standing to challenge the unauthorized use.

In Gieseking v. Urania Records, Inc., ${ }^{128}$ another recent New York case, the Civil Rights Law was also successfully invoked to protect a performer's rights in his performance. The late pianist Walter Gieseking had brought an action against

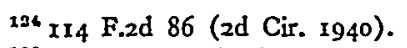

${ }^{130} 93$ F. Supp. 986 (S.D.N.Y. I950).

${ }^{228}$ r55 N.Y.S.2d I7I (Sup. Ct. 1956).

${ }^{125} 229$ F.2d at 493.
Id. at 986.
} 
the Urania Record Company for making unauthorized reproductions of his recorded performances and for using his name in connection with the sale of these records. The court denied defendant's motion to dismiss the complaint. The reasons were that even a performer in the public eye has a right of privacy under sections $5^{\circ}$ and $5^{\text {I }}$ of the New York Civil Rights Law and has a property right in his performance that it shall not be used for a purpose not intended, and particularly in a manner which does not fairly represent his service. The court did not rely on the Sharkey decision, but the rationale is much the same. The court further held that putting records on public sale did not amount to a forfeiture of the common-law rights in the records or, as the court put it, did not "dedicate the right to copy or sell the record." 129 As to this last point, the court cited the Capitol Records case as authority.

As to the second cause of action, namely unfair competition, the court in the Gieseking case merely stated that it came clearly within Metropolitan Opera Association v. Wagner-Nichols Recorder Corp. ${ }^{130}$

Thus, the right of privacy was protected and the performer's property right vindicated in the Gieseking and the Sharkey cases, although both performers were public figures.

In contrast to Sharkey and Gieseking, the Ettore case held that the New York Civil Rights Law "was intended to protect a personal as distinguished from a property right"131 and presumably was inapplicable to commercial televising of the filmed prizefight. Instead, "unfair competition" was relied on by the court, even though usually a cause of action in unfair competition requires "palming off" or at least some competition between plaintiff and defendant-neither of which was present here. ${ }^{\mathbf{1 3 2}}$ Apparently, it was considered that, even if Ettore had no right to privacy, his "right to publicity" was deserving of protection.

The previously mentioned use in Ettore of the Capitol Records decision as establishing that the plaintiff's common-law rights in his performance continued long after the match itself and its exhibition in movie theaters raises a question in another respect. Even if the majority in Capitol Records was correct in holding that sale of a record is not a publication, this does not mean that common-law rights in a motion picture continue past its time of publication, since the question of "publication" does not arise in regard to motion pictures in the same manner as for records. Judge Hastie's dissent considered this point and concluded that Ettore "published and dedicated the spectacle as completely as he knew how"; ${ }^{133}$ and, moreover, he emphasized that Ettore had made no effort to impose any $120 \mathrm{Id}$. at 173 .

${ }^{180} 199$ Misc. 786, roI N.Y.S.2d 483 (Sup. Ct. 1950), aff'd, 279 App. Div. 632, 107 N.Y.S.2d 795 (Ist Dep't r957).

131229 F.2d at 493.

${ }^{132}$ Cited by the court was Metropolitan Opera Association v. Wagner-Nichols Recorder Corporation, x99 Misc. 786, IoI N.Y.S.2d 483 (Sup. Ct. 1950), aff'd, 279 App. Div. 632, I07 N.Y.S.2d 795 (ISt Dep't 195I). There it was held that misappropriation of another's efforts was sufficient to give a cause of action and that direct competition and "palming off" were not required elements of unfair competition. But cf. Beecham v. London Gramophone Corp., 104 N.Y.S.2d 473 (Sup. Ct. I951).

${ }^{183} 229$ F.2d at 498. 
restriction upon the use of the film similar to the equitable servitude recognized in the Waring case. ${ }^{134}$

Thus, while the result in Ettore is clear enough, the ground on which it protected performers' rights is not. Despite the expressed intent to rely on Capitol Records, the court did not discuss whether the film showing Ettore's fight was published or unpublished; yet, in Capitol Records, the holding that sale of records was not publication constituted the predicate for the decision.

While to some Ettore marks a further step toward recognition of a performer's property right in his performance, the opinion there leaves much room for further clarification of the theory underlying protection of that right.

A distinct step toward crystallizing a property right theory under which performers' rights may be advocated has recently been taken in Hogan v. A. S. Barnes \& $C o ., \operatorname{lnc}_{.}{ }^{135}$ a trial court opinion which does not appear to have been appealed. Although this case did not concern the rights of a motion picture performer, the rationale of the decision appears to be applicable to such cases, since reliance seems largely to have been placed on cases dealing with performers' rights. The facts briefly were as follows:

The defendant, a publisher of books on sports, displayed in a book the name and photograph of Ben Hogan, the well-known golfer, without his permission. The defendant had sought a release from the plaintiff for the use of his photographs in return for payment of $\$ 100$ and two copies of the book. The plaintiff's letter in reply to this request consisted of three words: "Are you kidding?" The plaintiff informed the defendant, by a subsequent letter, that he refused to permit the use of his photograph and name in the proposed book, but defendant, nevertheless, used them, whereupon plaintiff brought action to recover damages on the following grounds:

I. invasion of plaintiff's right of privacy;

2. unfair competition;

3. unauthorized and uncompensated appropriation for commercial purposes of plaintiff's right of publicity;

4. libel; and

5. breach of a contract of quasi partnership in a joint adventure.

As to the invasion of the plaintiff's privacy, the court first stated that Hogan was a public figure who could not, and did not, complain that he had been unwillingly exposed to the glare of public scrutiny. Instead, the court said, the complaint was that the commercial value which attached to his name because he was a public figure had been exploited without his having shared the profits therefrom. Follow-

${ }^{184}$ Waring v. WDAS Broadcasting Station, Inc., 327 Pa. 433, 195 Atl. 63I (1937), where the orchestra leader was held entitled to the benefit of an equitable servitude when it was shown that a restrictive notice had been placed on each record released. Unlimited sale or lease for exhibition is generally considered to be publication. Patterson v. Century Productions, 93 F.2d 489 (2d Cir. 1937). ${ }_{130}{ }_{1}{ }_{4}$ U.S.P.Q. 314 (Pa. C.P. 1957). 
ing the decision in Haelan Laboratories v. Topps Chewing Gum, ${ }^{136}$ the court concluded that the plaintiff sought to vindicate, in the first count, not his right of privacy, but a right which was the very antithesis of the right of privacy-namely, the right to share in the income derived from the public exposure of his likeness and name. Therefore, there was no invasion of the plaintiff's right of privacy.

On the count of unfair competition, the court held that the plaintiff had an enforceable property right in the good will and commercial value of his name and photograph in connection with the game of golf. Therefore, the defendant's act of publishing and advertising the book constituted unfair competition as to the plaintiff in as much as by such act, the defendant misappropriated a property right of the plaintiff.

Thus far, the court followed precedent, and while the decision strengthens the line of cases protecting a vague property right of a performer in his performance and the publicity value derived therefrom, it adds nothing to the theory. The significance of the decision lies rather in the fact that the plaintiff was successful on his claim under the third count-i.e., a violation of his "right of publicity."

The court, in discussing the third count of the complaint, once more referred to the Haelan Laboratories case and analyzed the term "right of publicity" used in that case by the Second Circuit Court, saying: $:^{137}$

As we view the "right of publicity" . . . it is but another way of applying the doctrine of unfair competition. In essence, it is calling the property right, which must be found to exist in an unfair competition case, a "right of publicity". ...

The court expressed the view-rightly it is submitted-that a number of cases concerning complaints by public figures for invasion of their right of privacy should have been decided by applying the doctrine of unfair competition to a property right newly labeled the "right of publicity," instead of by granting relicf under a privacy statute in situations not properly within its scope.

Thus, the "right of publicity" as an aspect of the doctrine of unfair competition has been further developed by the Hogan decision. Once this right is generally admitted as a property right, the question, as pointed out by Hogan, is simply whether or not the plaintiff is justified in claiming a misappropriation of his right of publicity. If there is misappropriation, relief is available under the doctrine of unfair competition.

\section{Foreign Law}

Legal protection of performers is much less developed abroad than it is in the United States. Largely as the result of this lack of protection, performers are rarely in a position to obtain favorable individual contracts and encounter even greater difficulties in making satisfactory collective agreements with motion picture producers. The laws of the few countries which specifically protect performers usually

${ }^{136} 202$ F.2d 866 (2d Cir. 1953), cert. denied, 346 U.S. 816 (1953).

${ }^{237} \mathrm{XI}_{4}$ U.S.P.Q. at 320 . 
limit their protection to sound recordings and seldom protect performers against secondary use of these performances; other countries give performers some small protection under unfair competition or labor statutes. For purposes of comparison, a brief survey of these laws may be of some interest.

\section{Austria}

The Austrian copyright law ${ }^{138}$ probably provides better protection to the performers than does any other European law. Any person reciting or performing a work of literature or music has the exclusive right to record and broadcast his performance. ${ }^{139}$ Where a performance entails collaboration of several persons under a single director, the rights of exploitation vest in the director and the stars. ${ }^{140} \mathrm{How}$ ever, where a performance is to be broadcast, the question whether such exploitation is permitted is governed by the agreements controlling the legal relationship between the performers and the manager. ${ }^{141}$ In other words, whether a performer has any rights in televising a motion picture in which he participated, depends on his contract.

\section{France}

Statutory protection of performers is nonexistent in France, and protection under general rules of law is held to a minimum by the courts on the theory that only authors are entitled to benefit from literary and artistic property. ${ }^{142}$ The contracts between motion picture producers and performers show that almost total lack of legal protection of the performer aggravates the weak bargaining position of the performer due to the generally bad economic position of the French motion picture industry. For instance, one of the standard employment contracts contains the following provisions:

The producer has the right to exploit the film at his exclusive profit, including recording, radio, and television broadcasting. The work week covers six full working days. The producer is under no obligation to extend the employment contract, even though the film is not completed, and he may interrupt the employment up to six working days, during which time the performer is not entitled to any pay. The producer may substitute another performer without any payment other than the agreed salary and may transfer all rights and obligations under the contract, provided only the performer is paid his agreed salary. In case of any grave difficulty beyond the control of the producer (e.g., strikes, restrictions on the use of electricity

${ }^{288}$ Law of April 9, 1936, as amended.

${ }^{280} I d . \S 66(\mathrm{I})$.

${ }^{240} I d . \$ 66(2)$.

${ }^{142}$ Id. $\$ 66(3)$.

${ }^{142}$ Civ. Trib. Seine, Nov. 9, 1937, D.A. 1940.I18. There, the court said that as far as financial rights are concerned, only the author has an artistic property right, and not the actor or performer. Where a performance is incorporated on a sound track of a motion picture, the performer is presumed to have transferred all property rights at the time he received payment for recording his performance. Sce also Civ. Trib. Seine, April 23, I937, D.A. I939.129. This decision did, however, grant to the performer a "moral right" in his performance. Accord, Civ. Trib. Seine, March 8, 1954, [1954] Semaine Jurisdique II. 8114; Civ. Trib. Seine, Dec. I9, I953. 
or film), the producer has the right to rescind the contract; in that case, the performer may keep the salary received, but is entitled to no other payment.

\section{Germany}

The German copyright law protects performers as adapters in the case of sound recordings. ${ }^{143}$ In other cases, performers have to rely on the provisions of the Civil Code, ${ }^{144}$ or on the law concerning unfair competition. ${ }^{145}$

Employment contracts between producers and performers seem to be limited to provisions concerning salaries, vacation pay, etc.; the legal relationship between the parties is regulated by a still valid decree of the former Nazi Ministry of Labor. ${ }^{146}$ This decree provides in part as follows:

All property rights in the motion picture belong to the producer, including all rights to use the motion picture in ways unknown at the time the contract between producer and performer is made. Use of the motion picture on television is specifically granted the producer, provided the artistic reputation of the performer is not thereby damaged. The producer may cut or change the film, even after completion. Only the producer has the right to distribute publicity releases concerning the activities or pictures of the performer. Where a contract provides for the making of two feature films or employment for at least one year, the performer may not distribute his likeness to others for commercial purposes, even though such likeness may not refer to his employment. The producer may use the name and likeness of the performer for purposes of publicity. The performer has a right to screen credit, or to credit in connection with publicity, only where the contract expressly so provides. Further, the performer agrees to accept another role in the same film, or perform in a different film. If the services of a director or performer are not used within five months after the contract has been made, he may give one month's notice; after that time, the contractual relationship is terminated, without either party being liable for damages. Regular working hours are from 9 a.m. to 7 p.m.-i.e., ten hours per day. Overtime is paid at the rate of 25 per cent additional pay, $5^{\circ}$ per cent for Sundays and holidays. Where the services of the performer are not used for reasons beyond the producer's control, the performer is not entitled to any payment. However, during such time, he may work elsewhere, provided such other employment does not interfere with the plans of the first employer.

The German Draft Copyright Law of 1954 contains a whole chapter on protection of the performer. ${ }^{147}$ Thus, the artist whose performance has been filmed is

${ }^{133}$ Law of I90I, $\$ 2$, as added by the Act of 19 ro. However, the right of the performer is presumed to have been assigned to the record manufacturer unless there is an express reservation. German Supreme Court, Nov. 14, 1936, G.R.U.R. 1937, 73.

${ }^{144}$ Civil Code $\$ \$ 823,826$. ${ }^{146}$ Law on Unfair Competition $\$ 1$.

${ }^{140}$ Tarifordnung für Filmschaffende, Aug. 19, 1943, passed under $\$ \S 32(3)$ and 33 of the Labor Law of Jan. 20, 1934. As has been noted heretofore in this paper, the Tarifordnung has had a significant effect on authors' contracts with producers, even though it was not specifically applicable thereto.

${ }^{147}$ Sections $73-8 \mathrm{r}$. 
entitled to equitable payment for use of the motion picture on television, unless the performer is an employee of the telecaster and the performance took place within the scope of the employment and as part of his salaried duties. ${ }^{148}$

\section{Great Britain}

The Dramatic and Musical Performers' Protection Act, $1925^{149}$ gives performers a summary remedy against unauthorized use of their sound recordings, ${ }^{150}$ without, however, creating any specific right. ${ }^{151}$ There is no statutory protection of performers in the case of visual performances. ${ }^{152}$

British motion picture performers operate under one of two standard agreements. Artists engaged for a film on a daily salary basis are subject to the agreement dated December 5, 1947, between the British Film Producers' Association and the British Artists' Equity Association. Crowd artists, stand-ins, and doubles work under the Studio Standard Agreement, dated October 27, 1947, between the British Film Producers' Association and the Film Artists' Association. Some of the clauses of the first-mentioned agreement may be of interest here.

Producers must use a standard form of engagement ${ }^{153}$ which provides for minimum guaranteed periods of employment and salary. In the case of being on location more than 30 miles from London without working, the performer is entitled to half salary ${ }^{154}$ Working hours normally are a period not exceeding nine hours, ${ }^{155}$ overtime being paid at the rate of time and a half in the case of performers receiving $£ 30$ or less per day. ${ }^{156}$ The producer has the right to use the performer's likeness, autograph, or biography in connection with publicity of the film; but he may not use the performer's photograph or name in connection with the publicizing of other commercial goods without the performer's consent. ${ }^{157}$ The performer, during his engagement, may not, without the producer's written consent, grant press, radio, or television interviews dealing with the film, but he is entitled to the producer's consent (not to be unreasonably withheld) to the issue of any statement necessary for the protection of his reputation, such statement to be issued through the producer's publicity department. ${ }^{158}$ The performer is not entitled to claim any compensation in respect of loss of publicity or reputation in the event his engagement is terminated or his part in the film is omitted or changed. ${ }^{159}$

In the case that production of the film is prevented by reasons beyond the producer's control, the producer may suspend the contract for the duration of the emergency, ${ }^{100}$ or terminate the engagement on five working days written notice

${ }^{148}$ Draft Copyright Law of $1954, \S 74(2)$.

${ }^{160}$ Is \& 16 Geo. 5 , c. 46 . ${ }^{150} I d$. \$ $\mathrm{I}$.

${ }^{16 z}$ See Report of the Copyright Committee, presented by the President of the Board of Trade to Parliament, Oct. 1952, at p. 62 .

${ }^{189} 15 \& 16 \mathrm{GEO} .5$, c. $46, \$ \S 3$ and 40 protect the copyright owner of a motion picture against unauthorized televising.

${ }^{153}$ Studio Standard Agreement cl. 5 and $6 . \quad{ }^{104}$ Id. cl. 9.

${ }^{105} \mathrm{Id}$. cl. 12.

${ }^{167}$ Id. cl. $18(\mathrm{a})$.

${ }^{160}$ Id. cl. 18 (d).

${ }^{158} \mathrm{Id}$. cl. 15 .

${ }^{158}$ Id. cl. I8(b).

${ }^{100}$ Id. cl. 22 (a). 
upon payment of all salary due for services prior to the date of stoppage. ${ }^{101}$ If, after three weeks of suspension, the producer retains first call on the performer, and if the suspension continues beyond that time, the performer is entitled to a stipulated amount $^{182}$ to a maximum of $\oint_{100}$ per week.

\section{Mexico}

The new Mexican copyright law ${ }^{163}$ contains a definite provision for the protection of performers. Under article 68, performers of works performed on radio, television, in a motion picture, or by any other means capable of reproducing sound or image are entitled to payment for the use of their performance. In the absence of express agreement, this payment will be regulated by tariffs issued by the Secretariat of Education. ${ }^{164}$ If two or more performers are involved in the performance, the payment is distributed in such manner as they may agree. Thus, performers have a right to payment for televising their performance in a motion picture, even if they have no property right in the performance.

The organizations of actors and screen directors have concluded detailed collective agreements with the Mexican Film Producers' Association. The present agreement between producers and actors is dated September 9, r953, and contains, inter alia, the following provisions:

Any individual agreement between producer and performer without consulting the Union, is null and void, ${ }^{165}$ as is any agreement deviating from the provisions of the collective agreement, except where the individual agreement is more favorable. ${ }^{166}$ Service contracts may not be transferred or assigned by the producer without prior express consent of the performer and permission by the Union. ${ }^{107}$ Maximum daily working time is eight hours during daytime, seven hours during the night, and seven and one half hours in a "mixed" day. ${ }^{108}$

Three forms of individual contracts are permissible under the collective agreement:

(I) contracts per film, with a maximum of five work weeks, and minimum salaries of II,000 pesos for stars and 7,700 pesos for "first parts."

(2) contracts on a daily basis with double pay for overtime, and $357.5^{\circ}$ pesos per day with a two day minimum for "first parts."170

(3) contracts per film with a maximum of two work weeks. But recognized stars are excluded from this arrangement. ${ }^{171}$ The minimum salary for featured performers is 7,000 pesos.

The actors' minimum basic agreement is almost exclusively concerned with working conditions and minimum salaries; the screen directors' agreement, ${ }^{172}$ in

${ }^{10 x}$ Ibid. $\quad{ }^{103}$ Id. cl. 7.

${ }^{103}$ Published in 219 Diario Oficial no. 50 (1956).

${ }^{104}$ The writer is not informed whether these tariffs have yet been promulgated.

${ }^{105}$ 219 Diario Oficiaz no. 50, 5 a (1956).

${ }^{100} I d$. $\$ 7 \mathrm{a}$.

${ }^{107} I d . \$$ I $8 \mathrm{a}$.

${ }^{108}$ Id. \& $21 \mathrm{a}$

${ }^{160} 1 d$. $\$ 27 \mathrm{a}$.

${ }^{170} 1 d$. $\$ 27 \mathrm{a}(\mathrm{b})$.

171 Id. $\$ 27 \mathrm{a}(\mathrm{c})$.

${ }^{173}$ Sereen Directors' Contract, July 27, 1955. 
addition, stipulates certain rights which must be granted to the director. For instance, the name of the director must appear on the main title card for not less than ten feet, and no other name may be shown. ${ }^{173}$ The director's name must also be mentioned, with appropriate credit, in all publicity ${ }^{174}$ Minimum salaries are based on a per film and time basis, ${ }^{175}$ and the total salary is due only if the producer does not wish the director to complete the motion picture. ${ }^{176}$

\section{The "Neighboring Rights" Conventions}

The first concrete expression of the effort to protect performers by international agreement was made at the revision conference for the Berne Convention held in Rome in $1928 .{ }^{177}$ Voeu No. 5 Concerning the Protection of Performing Artists, proposed by the Italian delegation, read as follows: $:^{178}$

The Conference recommends that the Governments participating in the work of the Conference consider the advisability of adopting measures intended to protect the rights of performing artists.

In 1938 , a committee of experts on the rights of performers, broadcasting, television, and mechanical reproduction of sound met in Geneva and came to several "conclusions" on performers' rights. Point three of these conclusions provided in part as follows:

The performer is entitled to claim from his employer a separate renumeration ... if his performance is broadcast, even when his contract contains no provisions to that effect.

In 1939, the International Institute at Rome for the unification of private law convened a special committee of experts at Samaden, Switzerland, which drafted two conventions, the first one concerning the protection of performing artists and of producers of phonograph discs and similar instruments, and the second one "concerning the protection of radio emissions."

The Belgian Government proposed another provision regarding the protection of performing artists to be inserted by the Brussels conference of 1948 in the revised Berne Convention. ${ }^{179}$ However, largely due to the opposition of the authors' societies, no provision on performers' rights was included in the convention; instead, the conference adopted another voeu. ${ }^{180}$

Through the efforts of the Berne Union and the International Labor Organization, a mixed committee of experts met in Rome in November $195^{1}$ and drafted a

${ }^{173}$ Id. \$ 40 ,

${ }^{178} I d$. $\$ 45$.

${ }^{172} I d . \$ 4 \mathrm{I}$.

${ }^{278}$ Id. $\$ 46$.

${ }^{177}$ The International Labor Organization began to consider performers' rights in 1926.

${ }^{178}$ ACTES DE IA CONFERENCE 350 (1928).

${ }^{170}$ This proposal read: "Article II quater. The performance of a work which has or has not fallen into the public domain shall be protected subject to conditions to be established by the national . legislation of each Union Country."

180 "Voeu No. VIII, concerning the rights neighboring on Copyright, and particularly the protection of performing artists. Considering that the interpretations of performers have an artistic character, the Conference recommends that studies on neighboring rights be actively pursued particularly in regard to the protection of performing artists." ACTES DE LA CONFÉRÉNCE 587 (1948). 
"preliminary draft international convention regarding the protection of performers, manufacturers of phonographic records and broadcasting organizations." This socalled Rome Draft Convention gave the performers the right to authorize (or prohibit) the recording, communication to the public, and broadcasting of his performance. ${ }^{181}$ This draft convention was followed by a similar draft approved in July $195^{6}$ by a committee of experts which met in Geneva under the auspices of the International Labor Organization. Finally, another committee of experts on neighboring rights met in Monaco in March 1957 and produced a third draft convention.

The Monaco Draft Agreement, like the previous draft conventions, does not cover domestic situations, but "purports to regulate only situations in which rights and obligations extend across national frontiers."182 There seems to be no point in discussing these draft agreements in any detail, for they refer to protection of performers only in regard to their right to control live performances ${ }^{183}$ and acoustic recordings of such performances. ${ }^{184}$ Article two of the Monaco Draft Agreement provides in part that "the protection provided for by the preceding paragraph [i.e., national treatment in all states] shall include the prevention of fixation and broadcasting of a live performance when such fixation or broadcasting was not expressly or tacitly consented to by the performing artist." The word "performance" is defined ${ }^{185}$ as "the performance of literary or artistic works," and in the explanatory statement, it is pointed out that "it was held to be necessary to make this clarification primarily in order to avoid the impression that athletes, prizefighters, and other persons not performing literary or artistic works were within the scope of the draft." Furthermore, according to article six of the Monaco Draft Agreement, "no provision of this agreement may be interpreted as applying to the copying or any use (exhibition, broadcasting, or otherwise) of motion pictures or other visual and audio-visual fixations." 186

Thus, the scope of the Monaco Draft Agreement is limited to sound recordings of literary and artistic works. Consequently, this "neighboring rights" draft convention has little or no bearing on the questions with which we are concerned here.

\section{E. Some New Forms of Business Organization}

Reference has been made to the manner in which both authors and performers seek to protect the value of their services by contractual arrangements with producers. Above the lower echelon of performers, where contracts are quite standardized, one encounters many ingenious contractual variations designed to afford special protection to the "star" and particularly to aid him in retaining some portion of

${ }^{181}$ Rome Draft Convention art. 4(1) (195r).

${ }^{182}$ Explanatory statement accompanying the Monaco Draft Agreement.

${ }^{183}$ Monaco Draft Agreement art. 2(2) (1957).

${ }^{185}$ Id. art. 2(3).

${ }^{185}$ Id. art. 2(7).

${ }^{180}$ The explanatory statement to the Monaco Draft Agreement tells us that "as to performing artists, article 6 of the draft means that they are not granted any rights in respect to the copying or use of visual or audio-visual fixations." 
his earnings as against the onslaught of the tax collector. Also, the entertainment industry takes on an ever more cosmopolitan flavor as actors and writers leave their native countries for extended periods in order to immunize themselves from taxation in their native countries.

One of the offshoots of the unrelenting pressure of taxation has been the formation by various performers and writers of small production companies, which can be used to secure capital gains treatment. Here the "talent" protects the value of its services as against producers by simply becoming a producer of television shows and movies.

This process is not an easy one in view of the fact that the motion picture producers are producing more and more television films. However, the small production company has several advantages over the large producer: it is more flexible, and the range of its production cost is somewhat lower. These two advantages are still increased if the company is owned by the performers of the shows it produces or, at least, if it provides the star. The reason for the last named advantage is that the public gets surfeited with seeing the same show with the same performers every week and that stars become less and less willing to sell their services for weekly shows and are, therefore, more difficult to obtain. The possibilities for a producing company are then the better, the more stars it has available without having to hire them from the outside. Writers or adapters find it equally advantageous to form their own companies with their own stars, because in many instances, the creator loses control over the television show once the pilot film is completed. In some cases, where the creator is in a weak bargaining position, he has to be content with a small percentage of the royalties lasting only for the first time the show is on the air.

Another approach to the problem is the collaboration of sponsors in financing or cofinancing programs made by independent producers and those controlling the programs.

This development toward small, independent producing firms is still fluid and cannot yet be fully appraised. An analysis at this time would, therefore, be premature.

IV

\section{ConCLUSION}

This article discusses the rights of authors and performers with reference to both legal theory and economic organization. What justification is there for treating the problems of creators and performers in the same article, and what is the relevance of economic organization and activity to such joint treatment?

A successful motion picture or telecast must combine good creative art (story and direction) and good performance. But in considering legal protection of authors and performers, a distinction must be made between the two groups, because legal protection of each of the two groups rests on a different foundation. Authors' rights 
(even including those of directors) may be based either on the Copyright Act or on the common law, whereas performers must rely entirely on common-law protection, notably the theories of unfair competition, common-law literary rights, and in some cases, the right of privacy or the right of publicity. While the protection of creators is thus relatively clear-cut in theory, the legal basis of performers' protection is still in the process of rapid evolution.

An evaluation of the rights of authors or performers on the sole basis of the law involved-i.e., applicable statutes and court decisions-would not rest on a firm footing. Discussion of the legal protection of these rights, without some assessment of the extent to which the protection is really effective within the matrix of economic organization and activity, would result in a limited or even distorted view of a complex situation.

The French entertainment industry proves this point. Seemingly, the French author enjoys the most complete legal protection yet devised; but he is probably much less favored than the American author who, through joining with his fellows in a solid organization, has been able to attain an enviable bargaining position in motion pictures and television, where such a position has large financial values attached to it. Similarly, because they are highly organized, performers in the United States are much better off with only common-law protection than performers in some other countries who, technically, enjoy protection under copyright statutes. Moreover, in any small or financially weak movie or broadcasting industry, the talent groups may discover that even though the law grants them perfect protection and even though they are able to conclude favorable agreements with the producers, the first time they endeavor to take advantage of or enforce those agreements the unstable nature of the industry renders them powerless.

Thus, the law is complemented by contractual relationships between talent and producers which, in turn, depend on the standing of the movie and television industries in the national economy and, largely as a consequence of this standing, on the relative economic power of authors, performers, and producers. Since legal protection alone cannot guarantee talent an appropriate share of the revenues of the industry, discussion of both the legal and the economic aspects of their position is essential to an understanding of the position of talent in the entertainment industry.

It will be observed that despite the many legal and economic cross-currents, there is at least one unifying thread-the gradual development of new legislation, treaties, precedents, organization, and contracts to expand the right of the writer or performer to share in the economic benefits that flow from his creativity. In the dynamic entertainment industry, clearly finis has not yet been written to such development. 